\title{
RZYMSKOKATOLICKIE TOWARZYSTWO DOBROCZYNNOŚCI PRZY KOŚCIELE ŚW. KATARZYNY W PETERSBURGU W LATACH 1884-1919
}

\begin{abstract}
Wstęp
Dobroczynność należy do podstawowych zadań Kościoła w każdym kraju i w każdym czasie. W carskiej Rosji wszelka działalność Kościoła katolickiego była ograniczona, nie wyłączając sfery charytatywnej. Jednakże ta ostatnia miała najwięcej swobody działania. Autor podjął się zbadania takiego fenomenu, jakim była organizacja charytatywna o nazwie: Rzymskokatolickie Towarzystwo Dobroczynności przy kościele św. Katarzyny w Petersburgu. Poniżej będziemy używać skróconej nazwy: „Towarzystwo Dobroczynności” lub „Towarzystwo”, a pełnej nazwy tylko w wypadku, kiedy to jest konieczne. Przedstawiając w porządku chronologicznym powstanie, rozwój i losy tej organizacji, autor pragnie ukazać jej znaczenie dla przetrwania i rozwoju Kościoła katolickiego w Rosji na przełomie XIX i XX w. Artykuł niniejszy pokazuje na przykładzie omawianej organizacji charytatywnej nie tylko znaczenie filantropijne, lecz także społeczne, oświatowe i religijne tej organizacji.

Działalność omawianej organizacji dobroczynnej przedstawiamy na podstawie materiałów źródłowych, zachowanych w Bibliotece Uniwersyteckiej Katolickiego Uniwersytetu Lubelskiego, w archiwach i bibliotekach rosyjskich oraz w nielicznych opracowaniach ${ }^{1}$. Przy badaniu działalności Towarzystwa Dobro-

*Ks. Bronisław Czaplicki - dr historii, wykładowca Wyższego Seminarium Duchownego w Petersburgu.

${ }^{1} \mathrm{~W}$ dziesiątą rocznicę utworzenia Towarzystwa Dobroczynności, to znaczy w 1894 r. staraniem jego zarządu została wydana książka zatytułowana: „Charitas”. Księga zbiorowa wydana na rzecz r.-k. Towarzystwa Dobroczynności przy kościele św. Katarzyny w Petersburgu”, Petersburg 1894. W książce tej zamieszczone są artykuły, dotyczące życia Kościoła katolickiego w Rosji. Jednym z nich jest artykuł Józefa Czopowskiego pt. „Rz.-katolickie Towarzystwo Dobroczynności przy koś-
\end{abstract}


czynności szczególnie cennym źródłem są drukowane w języku rosyjskim roczne sprawozdania $^{2}$ zarządu Towarzystwa oraz informacje prasowe $\mathrm{z}$ tamtego czasu.

\section{Katolicka dobroczynność na tle ogólnej sytuacji w Rosji}

Aby lepiej zrozumieć znaczenie takiej organizacji charytatywnej, jakim było Rzymskokatolickie Towarzystwo Dobroczynności przy kościele św. Katarzyny w Petersburgu ${ }^{3}$, należy na początku podać kilka uwag na temat dobroczynności w Rosji i warunków, w jakich działał tam Kościół katolicki w omawianym przez nas czasie. Uwagi te podaję na podstawie literatury przedmiotu w języku polskim i rosyjskim.

W prawosławnej Rosji, podobnie, jak w innych krajach, panowała niesprawiedliwość społeczna i nędza. Było wielu osób biednych i sierot. Rządzący krajem carowie dostrzegali konieczność rozwiązania tego problemu i utworzenia odpowiednich placówek opieki. W działalność dobroczynną włączała się Cerkiew Prawosławna ${ }^{4}$. Niektórzy władcy wydali akty prawne, powołujące do życia sierocińce. Były też pomysły, aby sieroty, jako „własność” państwa przekazywać na wychowanie w rodziny, gdzie mogły znaleźć większą szansę przeżycia, ponieważ w sierocińcach była wielka śmiertelnośćs. Do XIX w. przeważała forma państwowej opieki charytatywnej oraz wydzielania środków na cele dobroczynne przez

ciele św. Katarzyny w Petersburgu". (Tamże, s. 575-585). Autorem artykułu był, adwokat, aktywny członek Towarzystwa. Podaje on informacje o powstaniu i pierwszych latach istnienia tej organizacji dobroczynnej. W wydanej przez Romualdę Hankowską książce: „Kościót św. Katarzyny Panny i Męczenniczki Aleksandryjskiej w Sankt-Petersburgu. Historia. Architektura. Wystrój wnętrza. Problemy rekonstrukcji i konserwacji, Warszawa 1997, s. 304, znajduje się artyku1: Towarzystwo Dobroczynności przy kościele św. Katarzyny", (Tamże, s. 242-244); Krótko o Towarzystwie Dobroczynności napisał także Ludwik Bazylow. Por. L. Bazylow, Polacy w Petersburgu, Wrocław 1984, s. 247-249; W wydawanym współcześnie przez parafię św. Stanisława w Petersburgu czasopiśmie „Nasz Kraj” w styczniowym numerze z 2003 r. zamieszczono bezimienny artykuł pod podobnym tytułem. Por. Rzymskokatolickie Towarzystwo Dobroczynności przy kościele św. Katarzyny w Petersburgu, „Nasz Kraj”, 1 (9) (2003) s. 4-7. Trudno tę pozycję uznać za opracowanie naukowe, ponieważ nie podaje żadnych odnośników, jednakże warta jest odnotowania jako próba zebrania pewnych informacji. Jest ona kompilacją wspomnianego artykułu J. Czopowskiego i bezimiennego artykułu 25-letni jubileusz rz.-kat. Towarz. Dobroczynności, wydrukowanego jako Dodatek ilustrowany do n-ru 140 „Dziennika Petersburskiego - 1909 r., s. 1-6.

${ }^{2}$ Były to drukowane broszury, w których przedstawiano rozliczenia finansowe organizacji za ubiegły rok działalności. Autor korzystał z tych sprawozdań, które zachowały się w Bibliotece Uniwesyteckiej Katolickiego Uniwersytetu Lubelskiego Jana Pawła II.

${ }^{3} \mathrm{~W}$ Petersburgu istniało wiele świątyń pod wezwaniem św. Katarzyny Aleksandryjskiej, dziewicy i męczennicy, należących do różnych wyznań chrześcijańskich. Powstawały one w czasie rządów Katarzyny II a nadanie kościołowi imienia patronki carycy, było próbą zdobycia cesarskiego patronatu nad wspólnotą parafian. Ponieważ przy świątyniach innych wyznań też istniały organizacje dobroczynne, więc w nazwie umieszczano przynależność wyznaniową.

${ }^{4}$ V.V. Belâkov, Sirotskie detskie učreždeniâ Rosii. Istoričeskij očerk, Moskva 1993, s. 6-8.

${ }^{5}$ Tamże, s. 10-13. 
władze, chociaż domy opieki mogły znajdować się w rękach Cerkwi, a nawet prywatnych.

Chociaż istniała dawna tradycja angażowania się zamożniejszych osób, w tym także rodzin carskich, w okazywanie pomocy potrzebującym, przebywających w sierocińcach, przytułkach i więzieniach, jednakże opieka ta była sporadyczna, nie systematyczna. W XIX w. zaczęły w Rosji powstawać więzienne komitety dobroczynne. W tego typu komitecie w Moskwie pracował „święty doktor”, jak go nazywano, pochodzący z Niemiec katolik, Fridrich Haass (w Rosji przyjęto nazywać go Fiodor Pietrowicz Gaaz). Dla niego więzień był człowiekiem godnym trudu i poświęcenia, i dla takich ludzi ten, kierujący się słowami Ewangelii człowiek świecki, poświęcił się bez reszty. Wiele zawdzięczali mu wywożeni na Syberię zesłańcy6.

W XIX w. rozwinęly się społeczne, to znaczy nie kierowane przez państwo formy opieki. Bogaci katolicy, wywodzący się zarówno z kręgów arystokracji, jak i działaczy przemysłu, wydzielali środki materialne na cele dobroczynne. Organizowali także komitety społeczne, utrzymujące poszczególne zakłady opiekuńcze, takie jak domy starców, sierocińce, szpitale, domy pracy, pracownie dla inwalidów itp. Arystokracja organizowała też imprezy, które miały pobudzić społeczeństwo do ofiar na rzecz potrzebujących. Były to dobroczynne bazary, loterie, bale, przedstawienia, przygotowanie i sprzedaż „kwiatków” na cele utrzymania zakładów dobroczynnych, zbiórki ofiar do skarbonek. Ofiary zbierane były w cerkwiach i kościołach, ale też na ulicach w określone dni ${ }^{7}$. Osoby arystokratycznego pochodzenia uważały za honor należeć do komitetów opiekuńczych i angażować się w pomoc biednym, zwłaszcza dzieciom. W ten sposób powstawały organizacje dobroczynne, a te z kolei zakładały poszczególne placówki opieki, takie jak sierocińce, nazywane zazwyczaj ochronkami, schroniska dla inwalidów, domy starców (przytułki), szpitale. Ten sposób pomocy wypływał z pobudek chrześcijańskich i humanitarnych. Placówki tego typu tworzone były zarówno przez prawosławnych, jak i przez inne wspólnoty wyznaniowe, zwłaszcza przez protestantów ${ }^{8}$.

Sytuacja Kościoła katolickiego w Rosji różniła się znacznie od sytuacji Cerkwi Prawosławnej - katolicyzm wraz z innymi wyznaniami chrześcijańskimi i niechrześcijańskimi był uważany za wyznanie „obce”. Katolicy czuli się obywatelami drugiej kategorii, władze rosyjskie ograniczały możliwości działania Kościoła katolickiego, widząc w nim zarzewie buntu podporządkowanych naro-

\footnotetext{
${ }^{6}$ P.V. Vlasov, Blagotvoritelnost' i miloserdie v Rossii, Moskva 2001, s. 58-69; Por. A. Nežnyj - sost., Vrata miloserdiâ. Kniga o doktore Gaaze, Moskva 2002.

${ }^{7}$ Blagotvoritelnost'i miloserdie v Sankt-Peterburge. Rubiež XIX-XX vekov, sost. V.N. Zanozina, E. A. Adamenko, Sankt-Peterburg 2000, s. 21-25.

${ }^{8}$ Informator o istniejących na początku XX w. w Petersburgu organizacjach dobroczynnych, oprócz dużej ilości prawosławnych, wymienia niemałą liczbę protestanckich towarzystw dobroczynności. Katolickich było znacznie mniej. Por. P.N. Isakov, Spravočnaâ knižka o blagotvoritelnyh učreždeniâh i zavedeniâh g. S.-Peterburga, S.-Peterburg 1911.

${ }^{9}$ Tak przyjęto thumaczyć na język polski używane w rosyjskim prawodawstwie pojęcie ,inostrannoje ispovedanie” (właściwie: „wyznanie zagraniczne”).
} 
dów. Przyjęcie katolicyzmu przez Rosjanina było traktowane jako przestępstwo przeciwko państwu ${ }^{10}$.

Katolicy, będący w zasadzie członkami narodów podbitych, inaczej niż Rosjanie rozumieli sens pracy charytatywnej. Swoje wysiłki w dziedzinie dobroczynności rozumieli oni nie tylko jako pomoc biednym, starcom, sierotom, lecz jako służenie społeczności katolickiej i narodowej. Rzecz jasna, nie mogli oni zajmować się potrzebującymi należącymi do innych wyznać, aby nie być oskarżeni o prozelityzm. Dobroczynność katolicka służyła więc jako czynnik integracyjny katolickiej mniejszości i konkretnych narodów. W Petersburgu powstało kilka katolickich Towarzystw Dobroczynnych, które nie były narodowe, ale w takim kierunku ewoluowały.

Katolickie organizacje charytatywne, podobnie jak i całe życie społeczne w Rosji, były ściśle kontrolowane przez władze państwowe. Musiały one przechodzić państwową rejestrację. Zarządy przeprowadzały spotkania robocze i zjazdy. Roczne sprawozdania, z dokładnym opisaniem działalności i rozliczeniem finansowym, były publikowane w specjalnych broszurach ${ }^{11}$.

Katolickie placówki dobroczynne powstawały na dwa sposoby. Pierwszym była jakaś inicjatywa, np. próba utworzenia sierocińca, aby po prostu pomagać sierotom. Ponieważ taki ośrodek należało rejestrować w organach państwowych, poszukiwano osób dla stworzenia komitetu, który wziąłby na siebie ochronę prawną tego przedsięwzięcia. Komitet rejestrował placówkę i reprezentował ją wobec władz. W znacznym stopniu troszczył się o zebranie funduszu na prowadzenie rozpoczętego dzieła. Tak było np. z powstaniem Rodziny Maryi ${ }^{12}$ - zgromadzenia zakonnego, założonego przez ks. Zygmunta Szczęsnego Felińskiego, a ukrywanego przez komitet opiekuńczy tego zakładu. Komitet troszczył się o stronę praw-

${ }^{10}$ W. Urban, Dzieje Kościoła w zaborze rosyjskim. Królestwo Polskie i tereny właczone do Cesarstwa Rosyjskiego, w: Historia Kościoła w Polsce, red. B. Kumor i Z. Obertyński, t. 2, cz. 1, Warszawa 1979, s. 423.

${ }^{11}$ Ustawa Towarzystwa Dobroczynności przy kościele św. Katarzyny w Petersburgu, § 18, „Nasz Kraj”, 1(9) (2003) s. 11-12. - (przedruk z: „Kraj” 8 (1884) s. 16).

${ }^{12}$ Rodzina Maryi powstała w Petersburgu w 1857 r. w budynku należącym do kościoła św. Katarzyny. Było to zgromadzenie zakonne, ukryte pod szyldem sierocińca. W 1858 sierociniec został przeniesiony na Wyspę Wasilewska, do domu baronowej Zofii Rudolfownej Meyendorf zd. Buol fon Schauenstein. Por. Z. Sz. Feliński, Pamiętniki, oprac. E. Kozłowski, Warszawa 1986, s. 448, 714. Dzięki staraniom baronowej Meyendorf władze państwowe 27 października 1859 r. zatwierdziły statut zakładu pod nazwą „Ustawy domu-przytułku dla ubogich rzymskokatolickiego wyznania w S.-Petersburgu". Miał mieć dwa oddziały, tzn. Przytułek dla starych kobiet i sierociniec dla dziewczynek. Pierwszą przewodniczącą Komitetu sierocińca była Izabella Adamowna Gagarina zd. Walewska, jej zastępczynią Z. Mayendorf. Do Komitetu opiekuńczego należały także Teodoryna Millot, księżna Golicyna i inne osoby. Ks. Z. Sz. Feliński otrzymał oficjalną nominację na kapelana otwartej kaplicy w listopadzie 1858 r. Por. H. E. Wyczawski, Arcybiskup Zygmunt Szczęsny Feliński 1822-1895, Warszawa 1975, s. 272-274; Por. Także: RGIA, F. 821, op. 125, d. 3025 - R-k. Bogodelni, priûty i blag. obŝestva, č. I, 1. 256 - Ustav ubežiŝa dlâ bednyh. 
ną, prowadził korespondencję i sprawozdania finansowe, chociaż nie ingerował w wewnętrzne sprawy zgromadzenia zakonnego ${ }^{13}$.

Innym sposobem było powołanie organizacji dobroczynnej, która rozwijając swoją działalność, otwierała nowe placówki i podejmowała różne inicjatywy charytatywne. Towarzystwa dobroczynności powoływały z kolei komitety odpowiedzialne za działalność poszczególnych swoich zakładów. Zarząd Towarzystwa, do którego wchodziły osoby pochodzenia arystokratycznego, reprezentował organizację wobec władz i zbierał fundusze na pokrycie kosztów utrzymania placówek oraz na budowę lub rozbudowę ich zaplecza. Przedstawicielom arystokracji łatwiej było zebrać potrzebne środki i przezwyciężać biurokratyczne przeszkody. Towarzystwa dobroczynności działały przy parafiach, co nie znaczy, że były parafialnymi. Częstokroć duchowni nie byli w stanie przeciwstawić się linii, narzuconej przez zarząd towarzystwa, co prowadziło do konfliktów. Proboszczowie, zwłaszcza syberyjscy, narzekali na to, że członkami towarzystw dobroczynności są niejednokrotnie osoby wrogo ustosunkowane do religijnego wychowania dzieci ${ }^{14}$. Ogólnie rzecz biorąc, towarzystwa dobroczynności pełniły jednak rolę integrującą środowisko katolickie.

\section{Powstanie i rozwój Rzymskokatolickiego Towarzystwa Dobroczynności przy kościele św. Katarzyny w latach 1884-1894}

\section{a) utworzenie Towarzystwa}

Wcześniej zauważyliśmy, że Rzymskokatolickie Towarzystwo Dobroczynności przy kościele św. Katarzyny nie było pierwszą tego typu organizacją w Petersburgu ${ }^{15}$. Nie było ono także organizacjąjednego narodu, ponieważ i parafia św. Katarzyny była wielonarodowa. Stopniowo jednak stawało się organizacją polska, choćby dlatego, że inne narodowości katolickie stolicy starały się utworzyć swoje organizacje dobroczynne. Statut Towarzystwa stał się wzorcem dla katolickich towarzystw w innych miejscowościach. Działalność tego Towarzystwa obejmowała

${ }^{13}$ Zakład, stworzony przez Rodzinę Maryi był nazwany przytułkiem (schroniskiem) dla biednych wyznania rzymskokatolickiego w Petersburgu.

${ }^{14}$ Por. Sprawozdanie ks. Aleksandra Bilakiewicza w: Majdowski, A, Kościót katolicki w Cesarstwie rosyjskim. Syberia. Daleki Wschód. Azja Środkowa, Warszawa 2001, s. 189; Tamże: Stan religijno-moralny parafii irkuckiej (1907). Sprawozdanie ks. Fryderyka Zyskara, s. 77-86.

${ }^{15}$ Francuskie Towarzystwo Dobroczynności w Petersburgu istniało od 1817 r. Por. „Detskaâ pomoŝ", 7 (1887) s. 219, Hronika russkoj blagotvoritelnosti. Od 1826 r. w Petersburgu istniał sierociniec francuski, przy którym też powstał szpital. Prawdopodobnie jego statut musiał zostać na nowo zarejestrowany w 1865 r. 25 marca 1865 r. zgodnie ze statutem, zatwierdzonym przez ministra spraw wewnętrznych 12 marca 1865 r., na plenarnym zebraniu dobrodziejów zostały wybrane władze Komitetu przytułku i szpitala. Przewodniczącą została hrabina Sofia Tołstaja a damy Francoise Jaume, Ljubow Fontana, Ernestyna Minulaw - zostały członkami Komitetu. Na sekretarza został wybrany baron Herschau. Por. RGIA, f. 821, op. 125, d. 3032 - Priût Dobrogo Pastyrâ, 1. 12-12 odwr. - Komitet priûta- v Med. Departament MVD 25 III 1865; Częstokroć rz-kat. Towarzystwo Dobroczynności przy kościele św. Katarzyny było uważane za „polskie”. 
cały Petersburg. Ta największa spośród katolickich organizacji dobroczynnych uformowała działaczy dla powstałych później organizacji społecznych. Towarzystwo nieustannie rozwijało zakres swojej działalności aż do wybuchu I wojny światowej w. 1914 r., kiedy to powstały nowe organizacje opiekuńcze, a Towarzystwo Dobroczynności stało się po prostu jedną z wielu katolickich organizacji charytatywnych w Piotrogrodzie ${ }^{16}$.

Za datę powstania Rzymskokatolickiego Towarzystwa Dobroczynności przy kościele św. Katarzyny w Petersburgu przyjmuje się rok 1884, kiedy to został zarejestrowany jego statut przez władze państwowe, chociaż próby jego utworzenia miały miejsce wcześniej ${ }^{17}$. Jego statut został przygotowany przez syndyka kościoła św. Katarzyny, senatora Karola Gartkiewicza ${ }^{18}$ już w 1882 r., nie spotkał się jednak z aprobatą ówczesnego proboszcza, dominikanina Flessa ${ }^{19}$. Dokumenty archiwalne wskazują na to, że to władze państwowe przeciwstawiały się powstaniu katolickiej organizacji dobroczynnej. W 1882 r. minister spraw wewnętrznych twierdził, że „istnienie przy katolickich kościołach jakichkolwiek towarzystw, nawet i dobroczynnych jest niepożądane, ponieważ te towarzystwa podlegałyby kierownictwu rzymskokatolickiego duchowieństwa”. Władze nie pozwalały także umieścić w statucie słów mówiących o udziale kapłanów w zarządzie Towarzystwa ${ }^{20}$ Statut został zatwierdzony przez władze państwowe dopiero 10 stycznia 1884 r. $^{21}$.

${ }^{16}$ Nazwa miasta Sankt-Petersburg na Piotrogród została zmieniona na fali uczuć antyniemieckich i patriotycznych w $1914 \mathrm{r}$.

${ }^{17} \mathrm{~W}$ zarządzie parafiami według prawodawstwa Katarzyny II powinni uczestniczyć przedstawiciele parafian, zwani syndykami. W wypadku kościoła św. Katarzyny było ich 8, po dwóch przedstawicieli 4 podstawowych narodowościowych, tzn. Francuzów, Niemców, Polaków i Włochów. Pod koniec XIX w. od tej zasady odstapiono i wybierano tylko 2 syndyków. Por. Czopowski, R.katolickie Towarzystwo Dobroczynności, s. 578. Na początku XX w. powstały osobne parafie: francuska M. B. Francuskiej i niemiecka - św. Bonifacego.

${ }^{18}$ Senator Karol Gartkiewicz był prezesem zarządu Towarzystwa Dobroczynności w latach 1895-1898 i 1900-1902.,,25-letni jubileusz rz.-kat. Towarz. Dobroczynności”, w: „Dodatek ilustrowany do nru 140 «Dziennika Petersburskiego»" z 1909 r., s. 4.

${ }^{19}$ Sytuacja taka wynikała z istniejącego w XIX w. planu rusyfikacji Kościoła katolickiego. Według tego planu, w 1879 r. odsunięto ze stanowiska proboszcza kościoła św. Katarzyny zasłużonego proboszcza, dominikanina, o. Jakuba Szkiłłądzia, sprowadzono zaś dominikanów z zagranicy, m. in. ojców Konstantego Flessa, Josepha Schumpa i Brunona Wolingera. Sytuacja zmieniła się dopiero po ponownym objęciu w 1883 r. parafii przez o. Szkiłłądzia. Por. S. Ptaszycki, $Z$ moich wspomnień z nad Newy, w: Z murów św. Katarzyny. Księga pamiatkowa b. wychowanek $i$ wychowanków gimnazjum przy kościele Świętej Katarzyny w Petersburgu, Warszawa 1933, s. 55-57.

${ }^{20}$ Rossijskij Gosudarstwennyj Istoričeskij Arhiv (Rosyjskie Państwowe Archiwum Historyczne - RGIA), F. 821, op. 125, d. 3025 - R-k. Bogodelni, priûty i blag. obŝestva, č. I, 1. 64 odwr.- DDDII - v Hoz. Departament, 1. 137 - [Spravka MVD].

${ }^{21}$ Józef Czopowski ubolewał, że stało się to bardzo późno nie bez winy pracujących w parafii kapłanów, chociaż katolicy licznie przybywający do Petersburga w poszukiwaniu pracy, byli częstokroć bardzo ubodzy. Zaznaczył, że wcześniej działały już francuskie i niemieckie organizacje dobroczynne. Por. Czopowski, R.-katolickie Towarzystwo Dobroczynności, s. 576. Jak można sądzić na podstawie informatora o istniejących w Petersburgu placówkach dobroczynnych na początku XX w., wydaje się, że niemieckie organizacje dobroczynne istniały przeważnie przy parafiach ewange- 


\section{b) Charakterystyka statutu}

Zgodnie ze statutem Towarzystwo stawiało sobie jako cel wspieranie pomoca osób wyznania rzymskokatolickiego, zamieszkałych w Petersburgu. Pomoc miała wyrażać się w wydawaniu produktów spożywczych, opału i odzieży, wydawaniu zapomóg, poszukiwaniu pracy, umieszczaniu osób starszych w przytułkach i innych zakładach, umieszczaniu młodzieży w szkołach, sierocińcach, a także organizowaniu za pozwoleniem władz szkół, schronisk, sierocińców ${ }^{22}$.

Członkowie Towarzystwa dzielili się na honorowych i rzeczywistych. Za członków honorowych uznawano te osoby, które wnosiły jednorazowo nie mniej niż 100 rubli, lekarzy i aptekarzy bezpłatnie pomagających ubogim i chorym oraz takich dobroczyńców, których tym tytułem uhonorował zarząd towarzystwa za ich szczególne zasługi. Członkowie rzeczywiści powinni byli wnosić do kasy Towarzystwa przynajmniej 10 rubli rocznie. Oprócz środków pochodzących ze składek, Towarzystwo zamierzało zbierać fundusze na swoją działalność na urządzanych w tym celu balach, koncertach, przedstawieniach, odczytach, zabawach oraz organizując kwesty w innych miejscach. Towarzystwo powinno było też stworzyć kapitał zapasowy w banku, aby korzystać z jego procentów ${ }^{23}$.

\section{Trzy dziesięciolecia ciąglego rozwoju}

W niniejszym rozdziale wyróżniamy trzy okresy istnienia i działalności Towarzystwa Dobroczynności. Dodajemy także jeden paragraf poświęcony Kołu Pań, które współdziałało z Towarzystwem, chociaż prowadziło osobną sprawozdawczość.

\section{a) inicjatywy pierwszego dziesięciolecia (1884-1894)}

W czasie swojego prawie 35-letniego istnienia Towarzystwo Dobroczynności podjęło szereg bardzo różnorodnych inicjatyw, które przedstawiamy zasadniczo w porządku chronologicznym. Raz podjęte inicjatywy były na ogół kontynuowane aż do czasu rozpadu Towarzystwa po rewolucji październikowej $1917 \mathrm{r}$.

Inicjatywy podjęte $\mathrm{w}$ roku powstania Towarzystwa można podzielić na trzy grupy: - pomoc dla młodzieży, utworzenie biura pracy i plan organizacji imprez, celem pozyskania funduszy. Za priorytetową uznano sprawę niesienia pomocy uczącej się młodzieży. Już w pierwszym roku istnienia Towarzystwa stworzono

lickich. Por. P.N. Isakov, Spravočnaâ knižka o blagotvoritelnyh učreždeniâh i zavedeniâh g. S.-Peterburga, Sankt-Peterburg 1911.

${ }^{22}$ RGIA, F. 822, op. 4., d. 19155, k. 3; Por. też: Ustawa Towarzystwa Dobroczynności przy kościeleśw. Katarzyny w Petersburgu, „Nasz Kraj” 1(9) (2003) s. 11-12. - przedruk z: „Kraj”, 8 (1884) s. 16-17.

${ }^{23}$ Ustawa Towarzystwa Dobroczynności przy kościele św. Katarzyny w Petersburgu, „Nasz Kraj”, 1(9) (2003) s. 11-12. - (przedruk z: „Kraj”, 8 (1884), s. 16). 
fundusz dla studentów, wspierano kilkanaście dziewcząt w sierocińcu Rodziny Maryi (ouvroir) ${ }^{24}$.

Aby stworzyć fundusz pomocy uczącej się młodzieży, na posiedzeniu zarządu Towarzystwa 31 października 1884 r., senator K. Gartkiewicz, profesor Włodzimierz Spasowicz ${ }^{25}$, redaktor polskiego czasopisma „Kraj” Erazm Piltz ${ }^{26}$ i urzędnik Narzymski złożyli na ten cel 8 tys. rubli. W ten sposób powstał pierwotny kapitał. Warto tu zauważyć, że organizacje dobroczynne starały się utworzyć stały kapitał na jakiś cel, pieniądze przechowywać w banku, a korzystać tylko z procentów i nowych wpływów. Jednakże nie udało się, jak planowano, stworzyć zespołu pań, które organizowałyby zabawy i inne imprezy, z których dochód szedłby na cele dobroczynne, zwłaszcza na pomoc dla uczącej się młodzieży szkół wyższych. Kapitał Towarzystwa wzrósł znacznie dopiero w 1887 r., kiedy to otrzymało ono fundusz 47.000 rubli, zapisany mu przez zmarłego wtedy emerytowanego generała Oktawiusza Augustynowicza. Inicjatywa powołania biura pośrednictwa w poszukiwaniu pracy była dobra i potrzebna, lecz pomimo wsparcia informacyjnego ze strony czasopisma „Kraj”, ilość podań z prośbą o pomoc wielokrotnie przekraczała ilość zaoferowanych miejsc pracy ${ }^{27}$. Zarząd Towarzystwa zdawał sobie też sprawę, że będzie musiał zaspokoić napływające prośby o pomoc doraźną. Dlatego Towarzystwo starało się o zdobycie funduszy na ten cel i na utrzymanie istniejących i powołanie nowych placówek dobroczynnych ${ }^{28}$.

W 1885 r. Towarzystwo zwróciło się do władz miasta Petersburga o pozwolenie na utworzenie sierocińca dla chłopców: sierot i synów biednych rodziców w wieku $6-12$ lat, katolików bez względu na narodowość. Przedstawiło projekt statutu sierocińca. Chłopcy mieli zdobywać umiejętność czytania i pisania oraz nauczyć się podstawom rzemiosła. Jednakże minister spraw wewnętrznych pozwolenia nie dał. Chodziło o to, aby nie dopuścić wpływu duchowieństwa na wychowanie chłopców ${ }^{29}$. Ponieważ nie było katolickiego sierocińca dla chłopców, postanowiono umieścić 8 chłopców w internacie przy szkole męskiej, istniejącej

${ }^{24} \mathrm{~W}$ oficjalnych dokumentach podawano po prostu „ouvroir” przy 14 Linii Wyspy Wasilewskiej nr 25, czasami pisano: sierociniec hrabiny Meyendorf lub też księżnej Gagarin. Por. RGIA, F. 821, op. 125, d. 3031 - Delo o ustanovlenii nadzora nad priûtom, 1. 7; Zwyczaj nazywania tego zakładu z francuska „ouvroir” (pracownia) prowadzi niezorientowanych autorów do wniosku, że był on francuskim, zwłaszcza, że nieopodal na tej samej Wyspie Wasilewskiej znajdował się rzeczywiście francuski zakład „Dobrego Pasterza”. Por. Rzymskokatolickie Towarzystwo Dobroczynności przy kościele św. Katarzyny w Petersburgu, s. 4.

${ }^{25}$ Włodzimierz Spasowicz - były profesor Uniwersytetu Petersburskiego. Por. Ptaszycki, Z moich wspomnień z nad Newy, w: Z murów św. Katarzyny, s. 51-52; Por. także: L. Bazylow, Polacy w Petersburgu, Wrocław-Warszawa-Kraków 1984, s. 290-293.

${ }^{26}$ Erazm Piltz przybył do Petersburga z Warszawy. Tygodnik „Kraj” zaczął wydawać w 1882 r.

Por. Ptaszycki, Z moich wspomnień z nad Newy, w: Z murów św. Katarzyny, s. 52.

${ }^{27}$ Czopowski, R.-katolickie Towarzystwo Dobroczynności, s. 580.

${ }^{28}$ R. Hankowska, Kościót św. Katarzyny w Sankt-Petersburgu, Warszawa 1997, s. 242-245.

${ }^{29}$ RGIA, F. 821, op. 125, d. 3025 - R-k. Bogodelni, priûty i blag. obŝestva, č. I, 1. 80-96 odwr. - [O razrešenii priûta malčikov]. 
przy kościele św. Katarzyny ${ }^{30}$. Do sprawy sierocińca dla chłopców powrócono w przyszłości.

Towarzystwo postanowiło też utworzyć przytułek dla starców. Być może, rozpoczął on swoją działalność jeszcze w 1885 r. Aby mieć stały lokal na ten cel, 24 kwietnia $1886 \mathrm{r}^{31}$ zarząd Towarzystwa Dobroczynności zwrócił się do metropolity mohylowskiego Aleksandra Gintowta z prośbą o przekazanie mu jednego z domów znajdujących się obok kościoła Nawiedzenia NMP na katolickim, tzw. Wyborskim Cmentarzu, aby w nim urządzić Przytułek św. Maryi dla starych kobiet. Prośbę Towarzystwa poparł proboszcz kościoła, ks. Zacharewicz. W ten sposób powstała placówka, która w sprawozdaniach Towarzystwa nazywana jest Przytułkiem św. Maryi. Już w 1886 r. zamieszkało tam 20 kobiet, utrzymywanych przez Towarzystwo Dobroczynności. Ponieważ 1 stycznia 1886 r. fundusz stały Towarzystwa wzrósł do 33103 rubli 17 kopiejek, mogło ono wydawać miesięczne zapomogi biednym, w internacie przy szkole męskiej kościoła św. Katarzyny utrzymywać 8 chłopców, a w sierocińcu „ouvroir” wspierać 16 dziewczynek $^{32}$.

7 marca 1887 r. pod przewodnictwem metropolity mohylowskiego, A. Gintowta odbyło się roczne zebranie Towarzystwa Dobroczynności. Według sprawozdania za miniony 1886 rok Towarzystwo liczyło 80 członków honorowych i 394 rzeczywistych. Wydawało 211 każdomiesięcznych, 220 jednorazowych i 166 nadzwyczajnych zapomóg. W sprawozdaniu podano, że w sumie pomoc otrzymywało prawie 800 osób, w tym 123 studentów i 123 osoby, utrzymywane w przytułkach, szkołach i sierocińcach. Konkretnie zapis ten oznaczał, że Towarzystwo utrzymywało: w internacie progimnazjum męskiego przy kościele św. Katarzyny - 29 stypendystów, w przytułku św. Maryi na Cmentarzu Wyborskim - 37 starców, w sierocińcu „ouvroir” - wspomagało 55 dziewczynek, dzieci biednych rodziców lub sierot. Towarzystwo pośredniczyło także w poszukiwaniu pracy. Na 352 podania $\mathrm{z}$ prośbą o pomoc $\mathrm{w}$ jej znalezieniu, zrealizowano 30 . Towarzystwo zebrało w 1887 roku - 19287 r. 25 kop., a wydało - 19739 r. 53 kop. ${ }^{33}$.

Dziewczęta sieroty można było umieszczać w sierocińcu Rodziny Maryi, niektóre także we francuskim przytułku-sierocińcu „Dobrego Pasterza”34. Natomiast sierocińca dla chłopców w dalszym ciagu nie było. Zarząd Towarzystwa zdawał sobie sprawę, że umieszczanie chłopców-sierot $\mathrm{w}$ internacie progimnazjum męskiego, nie jest dobrym rozwiązaniem.

${ }^{30}$ Czopowski, R.-katolickie Towarzystwo Dobroczynności, s. 581-582; W internacie mieszkało ok. 80 uczniów, spośród których około 50 na koszt administracji parafii. Por. F. Śliwiński, Reformy prof. Rudzkiego, w: Z murów św. Katarzyny, s. 215.

${ }^{31}$ J. Czopowski podaje, że przytułek św. Maryi został otwarty już w 1885 r. Por. Czopowski, R.-katolickie Towarzystwo Dobroczynności, s. 581.

${ }^{32}$ „Detskaâ pomoŝ”, 7 (1886) s. 269 - Hronika russkoj blagotvoritelnosti.

${ }^{33}$ Tamże, s. 220-221.

${ }^{34}$ Było to pierwotnie schronisko dla osób starych i dzieci, utworzone przez Francuzów i kierowane przez Włoszkę Fanny Jaume. Z czasem postanowiono przeprofilować schronisko na miejsce odnowy moralnej dla zagrożonych upadkiem kobiet, dlatego nadano mu nazwę „Dobrego Pasterza”, chociaż w dalszym ciagu mieszkały tam dziewczynki - sieroty. Por. RGIA, f. 821, op. 125, d. 3032 - Priût Dobrogo Pastyrâ, 1. 1-2 - Ustav osobogo priûta v SPb. dlâ lic r.-k. ispovedanâ ženskogo pola. 
Pojawiła się inicjatywa Niemca, zegarmistrza Fichtnera, który 29 marca 1886 г. ofiarował na sierociniec swój dom przy 9 Linii nr 60 na Wyspie Wasilewskiej, lecz zapisał go nie Towarzystwu Dobroczynności, lecz administracji kościoła św. Katarzyny ${ }^{35}$, z zastrzeżeniem, że będą do niego przyjmowani tylko chłopcysieroty niemieckiego pochodzenia i jeśli powstanie osobna niemiecka parafia, to sierociniec będzie należał do niej. Zgodnie z życzeniem ofiarodawcy kierować sierocińcem powinien kapłan kościoła św. Katarzyny, odpowiadający za duszpasterstwo wśród Niemców-katolików ${ }^{36}$. Towarzystwo Dobroczynności, chociaż mające Niemca jako prezesa, takich warunków nie mogło przyjąć.

Według sprawozdania za $1887 \mathrm{r}$. Towarzystwo prowadziło podobne działania, co i w poprzednich, z tym, że zwiększyły się koszty, bo w internacie utrzymywało 30 młodzieży, a w przytułku 34 kobiety i 3 mężczyzn ${ }^{37}$.

Towarzystwo Dobroczynności, od lat planujące utworzenie sierocińca dla chłopców, popierało inicjatywę wikariusza kościoła św. Stanisława, ks. Antoniego Maleckiego, który zaczął zbierać chłopców-sieroty w wynajętym mieszkaniu w 1889 r. Jednakże nie mogło ono do czasu oficjalnej rejestracji, wydzielać na ten zakład pieniędzy. Inicjatywę tę wsparła bogatym darem parafianka Wiktoria Piotrowska, a także inne osoby duchowne i świeckie. Sierociniec mieścił się na Placu św. Michała Archanioła. Już w 1890 r. ks. Malecki zaprosił do pracy w sierocińcu niedawno powstałe honorackie zgromadzenie Córek Najczystszego Serca NMP, na czele którego stała jego stryjeczna siostra, m. Paula Malecka ${ }^{38}$. Początkowo sierociniec nie był zarejestrowany. Dzięki pomocy Towarzystwa Dobroczynności legalizacja sierocińca nastąpiła 31 grudnia 1890 r. ${ }^{39}$. Jednakże Ministerstwo oświa-

${ }^{35}$ BKUL, Rkp. 780, k. 39-43, [Plan zabudowy].

${ }^{36}$ Dom sierocińca Fichtnera był murowany 2-piętrowy, w podwórzu było 3 domki i dwie szopy oraz murowana pralnia i woda doprowadzona do podwórza. Nieruchomość została oceniona na sumę ok. 10 tys. rubli. Chłopcy powinni mieć utrzymywanie w sierocińcu, a naukę szkolną pobierać w miejskich szkołach. Ponieważ w tym czasie powstawała osobna niemiecka parafia, korzystała ona z kaplicy przy sierocińcu oraz z pomieszczeń sierocińca, co znacznie obciążało budżet sierocińca i wywoływało konflikty z administracją kościoła żw. Katarzyny. Por. RGIA, F. 821, op. 125, d. 3026, 1. 54. [Delo prijuta Fihtnera]. Na podstawie wydarzeń, które nastąiły później, można przypuszczać, że za takim pomysłem stali kapłani niemieccy, pracujący przy kościele św. Katarzyny. Sierociniec otwarto dopiero w lutym 1893 r. Istniała tam kaplica pod wezwaniem Najświętszego Zbawiciela, w której odprawiano Msze św. z kazaniem w języku niemieckim. Por. Katolik nad Newa, Kalendarz Rz-katolicki na rok 1912 „Pod znakiem krzyża”, s. 71-73.

37 „Detskaâ pomoŝ”, 6 (1888) s. 191 - Hronika russkoj blagotvoritelnosti.

${ }^{38}$ ACSM, E I, t.5, E. Gołębiowska, Wspomnienie z historii Zgromadzenia Sióstr Córek Najczystszego Serca NMP, mps., bmrw., s. 12.

${ }^{39}$ Por. A. Woycicki, Zaktady wychowawcze ks. Maleckiego w Piotrogrodzie w: Polski Kalendarz Piotrogrodzki na 1917 r., s. 158-163. Por. ACSM, Seria E. II. t. 2, Historia Zgromadzenia Córek Serca Maryi, cz. I, napisana przez Matkę Kingę Zakrzewską (mps, bmrw, dalej: Zakrzewska, Historia Zgromadzenia), s. 67-70; Ks. F. Rutkowski napisał w biografii przyszłego biskupa A. Maleckiego, że sprawę legalizacji sierocińca wzięli na siebie senator Karol Gartkiewicz i generał Nowicki. Ponieważ minister spraw wewnętrznych hr. Tołstoj był przeciwny temu, więc sprawa ta została załatwiona w czasie jego urlopu 19 (31) grudnia 1890 r. Por. Rutkowski, Biskup Antoni Malecki, s. 21. 
ty zażąałało jasnego zaznaczenia w statucie, że wszystkie bez wyjątku przedmioty wykładane są w języku rosyjskim, podręczniki muszą być zatwierdzone przez ministerstwo, nauka pisania i czytania ma być po rosyjsku, nauczyciele mają być zatwierdzeni przez odpowiednie władze oświatowe ${ }^{40}$. Sierociniec wkrótce stał się najważniejszą placówką spośród tych, którymi opiekowało się Towarzystwa Dobroczynności. Placówka ta pochłaniała większość funduszy Towarzystwa ${ }^{41}$.

Roczne zebranie towarzystwa w 1890 r., które podsumowywało pracę Towarzystwa w 1889 r., prowadził generał baron L. Zeddeller, prezes zarządu w latach 1884 - 189542. Liczba członków wzrosła do 431. Wydano 656 zapomóg dla 496 osób. Dochód Towarzystwa wynosił 21897 r. 15 kop., a łączna wartość posiadanych przez Towarzystwo papierów wartościowych zwiększyła się do 115. 650 rubli43.

W sprawozdaniu za 1890 r. Towarzystwo wyszczególniło, że okazywało pomoc uczącym się, wspierało „ouvroir”, internat guwernantek i sierociniec dla chłopców przy ul. Miaśnickiej $20^{44}$, w którym było wtedy 14 chłopców. Odnotowano tam także, że uprzednio Towarzystwo wspierało internat dla chłopców przy kościele św. Katarzyny, ale ponieważ chłopcy ci często nie kończyli szkoły, więc w 1889 r. administracja kościoła internat zamknęła. Wobec tego Towarzystwo postanowiło wspierać materialnie proces nauki ośmiu chłopców, których po zamknięciu internatu umieszczono w domach prywatnych. W „ouvroir” Towarzystwo opiekowało się 53 dziewczętami, w sierocińcu „Dobrego Pasterza”"45 - trzema, a w przytułku św. Maryi przy kościele na Wyborskiej Stronie Towarzystwo utrzymywało 4 mężczyzn i 33 kobiety ${ }^{46}$. Jak widzimy z treści sprawozdania, nową inicjatywą Towarzystwa było utworzenie internatu dla guwernantek.

Ze sprawozdania za $1891 \mathrm{r}$. widać, że Towarzystwo starało się być wierne swojemu priorytetowi, to znaczy pomaganiu w wychowaniu dzieci i młodzieży: utrzymywało szkoły elementarne ${ }^{47}$ i sierociniec dla chłopców, wspomagało dziew-

${ }^{40}$ RGIA, F. 821, op. 125, d. 3025 - R-k. Bogodelni, priûty i blag. obŝestva, č. I, 1. 194-195 - Ministerstvo Nar. Prosvâŝeniâ - Upravlâûsemu MVD 16 IX 1890.

${ }^{41}$ Czopowski, R.-katolickie Towarzystwo Dobroczynności, s. 582.

${ }^{42}$ Ptaszycki, Z moich wspomnień z nad Newy, w: Z murów św. Katarzyny, s. 54. Por. „25-letni jubileusz rz.-kat. Towarz. Dobroczynności”, w: ,Dodatek ilustrowany do nru 140 «Dziennika Petersburskiego»" z 1909 r., s. 4.

${ }^{43}$ „Detskaâ pomoŝ”, 6 (1890) s. 202 - Hronika russkoj blagotvoritelnosti.

${ }^{44}$ Nowy adres sierocińca ks. A. Maleckiego.

${ }^{45}$ Sierociniec i przytułek francuski dla dziewcząt i kobiet zagrożonych demoralizacją. Por. RGIA, f. 821, op. 125, d. 3032 - Priût Dobrogo Pastyrâ, 1. 1-2 - Ustav osobogo priûta v SPb. dlâ lic r.-k. ispovedanâ ženskogo pola.

${ }^{46}$ Otčët pravleniâ rimsko-katoličeskogo Blagotvoritelnogo obŝestva (učreždënnogo v 1884 g.) pri cerkvi Sv. Ekateriny v S.-Peterburge za 1 ânvarâ 1890 - 1 ânvarâ 1891, S.-Peterburg 1891, s. 3.

${ }^{47}$ Szkoła Elementarna przy kościele św. Katarzyny powstała w 1885. Por. M. Rzeszotarska, Szkoła Elementarna, w: Z murów św. Katarzyny, s. 165-166. Była to szkoła 2-klasowa dla najbiedniejszych dzieci (szkoła początkowa). W takich szkołach nie tylko uczono podstawowych przedmiotów, lecz również zajęć praktycznych. W 1906/1907 roku szkolnym do programu kl. 2 szkoły elementarnej dodano prace ręczne. Por. B KUL, Rkp. 782, Raspredelenie urokov v Elementarnoj škole; W 1907/1908 roku szkolnym w elementarnej szkole przy kościele św. Katarzyny uczono re- 
czynki przebywające w sierocińcu, fundowało stypendia dla uczniów i studentów. Oprócz tego pomagało szpitalom, w których leczyli się katolicy i udzielało zapomóg na święta. Dochód w 1891 r. wynosił ok. 23 tys. rubli, a rozchód ok. 25 tysięcy. Deficyt został pokryty z kapitału zapasowego, który wynosił ponad 121 tys. rubli. Natomiast suma pochodząca ze składek członkowskich zmniejszyła się, co świadczy o gaśnięciu członków. Jednak zaczęły powstawać oddzielne grupy członków, zwane kołami, które wspierały konkretne inicjatywy ${ }^{48}$.

W 1893 r. utworzono koło pomocy młodzieży uczącej się w szkołach średnich z inicjatywy p. R. Sendziuka. Działała też szkoła elementarna ${ }^{49}$. W tym czasie biskup Albin Symon ${ }^{50}$, sufragan archidiecezji mohylowskiej, utworzył sierociniec dla niemowląt, w którym również podjęły pracę siostry sercanki. Przyjmował on dzieci z najbiedniejszych rodzin, zagrożone demoralizacją ${ }^{51}$.

W związku ze zbliżającą się 10 rocznicą istnienia Towarzystwa Dobroczynności Wałużynicz-Kościuszko zaproponował wydanie informatora o życiu Kościoła katolickiego w formie książkowej. Powstała praca zbiorowa, którą tu cytujemy, pod tytułem „Charitas”. Księga zbiorowa wydana na rzecz r.-k. Towarzystwa Dobroczynności przy kościele św. Katarzyny w Petersburgu". W książce zamieszczono różne artykuły, w tym także cytowany tu artykuł J. Czopowskiego ${ }^{52}$.

Sprawozdanie za 1894, jubileuszowy rok istnienia Towarzystwa pokazuje, że opiekowało się ono tymi samymi placówkami, co i poprzednio. Dowiadujemy się z niego, że sierocińcu, który znowu zmienił adres i mieścił się w domu nr 116 przy Ekaterininskim kanale przy moście Alarczyn, przebywało 42 chłopców ${ }^{53}$. W sierocińcu „ouvroir” przy 14 Linii Wyspy Wasilewskiej, pod koniec roku Towarzystwo dawało stypendium 54 dziewczynkom i 1 staruszce. W przytułku „Dobrego Pasterza" opiekowało się 2 dziewczynkami, w przytułku św. Maryi na Cmentarzu Wyborskim utrzymywało 4 mężczyzn i 29 kobiet (na początku roku) i 3 mężczyzn i 35 kobiet (na końcu roku). Przy Towarzystwo działał nadal Komitet poszukiwania pracy $^{54}$.

ligii, języka rosyjskiego i polskiego, arytmetyki, kaligrafii i rysunków. Por. B KUL, Rkp. 782, k. 17-18, Vedomost o sostoânii mužskogo Elementarnogo Učiliŝa...

${ }^{48}$ „Detskaâ pomoŝ”, 14 (1892), c. 489 - Hronika russkoj blagotvoritelnosti.

${ }^{49} \mathrm{~W} 1893$ Naczelnik miasta Petersburga informował DDDII, że przy kościele św. Katarzyny od 150 lat istnieje szkoła męska, w której wówczas było 75 uczniów w internacie i 168 przychodzących. Szkoła żeńska istniała od 1839 r. Było 123 uczennice w internacie oraz 130 dochodzących. Ponadto w szkole elementarnej było 20 uczennic. Por. RGIA, F. 821, op. 125, d. 3028, R-k. priûty i blagotvoritelnye obŝestva, č. V, 1. 164-166 - SPb. Gradonačalnik - v DDDII 18 II 1893.

${ }_{50}$ Symon Franciszek Albin, w: Encyklopedia Powszechna, wyd. „Gutenberg”, Kraków brw., s. 285.

${ }^{51}$ ACSM, Seria E. II. t. 2, Zakrzewska, Historia Zgromadzenia, s. 74-75.

${ }^{52}$ „Charitas”. Księa zbiorowa wydana na rzecz r.-k. Towarzystwa Dobroczynności przy kościele św. Katarzyny w Petersburgu", Petersburg 1894; Tamże: Czopowski, R.-katolickie Towarzystwo Dobroczynności, s. 582.

${ }^{53}$ Kolejny adres sierocińca ks. Maleckiego.

${ }^{54}$ Otčët pravleniâ rimsko-katoličeskogo Blagotvoritelnogo obŝestva (učreždënnogo v 1884 g.) pri cerkvi Sv. Ekateriny v S.-Peterburge za 1 ânvarâ 1894 - 1 ânvarâ 1895, S.-Peterburg 1895, s. 13. 
Wśród placówek, utrzymywanych przez Towarzystwo Dobroczynności pojawił się utworzony w 1894 r. z inicjatywy członków Towarzystwa R. Sendziuka i Jałowieckiego, Dom Pracy ${ }^{55}$, mieszczacy się początkowo przy ul. Torgowaja, a potem ze względu na szczupłość pomieszczenia, w październiku 1895 r. przeniesiony do budynków parafialnych przy kościele św. Stanisława przy ul. Małaja Masterskaja ${ }^{56}$. Regulamin ośrodka nie przewidywał tam internatu, lecz stworzył warunki do przebywania razem z pracującymi matkami, ich małych dzieci, które miały zapewnioną opiekę. Także Dom pracy został powierzony opiece sióstr sercanek. W domu tym przychodzące kobiety mogły wykonywać określone prace za wynagrodzeniem lub uczyły się kroju i szycia. Siostry, korzystając z okazji dokształcały je oraz ich dzieci w zakresie wiedzy religijnej. Uczyły dzieci katechizmu i przygotowywały do przyjęcia Sakramentów św. ${ }^{57}$.

Oprócz Domu Pracy, w 1894 r. Towarzystwo Dobroczynności staraniami inżyniera Gustawa Kamińskiego utworzyło też Kuchnię Studencką (tanią stołówkę) przy ul. Zabałkanskij Prospekt 20. Korzystali z niej biedni i młodzież szkolna. Inicjatorami jej powstania byli profesorowie Aleksander Rudzki, syndyk Kościoła św. Katarzyny oraz prof. Wiktor Staniewicz, który pełnił przez szereg lat funkcję jej opiekuna: Materialnie wspierał Kuchnię znany w Warszawie i Petersburgu bankier i filantrop Hipolit Wawelberg ${ }^{58}$.

\section{b) rozwój Towarzystwa w drugim dziesięcioleciu istnienia (1894-1904)}

W drugim dziesięcioleciu swojego istnienia Towarzystwo Dobroczynności zasadniczo kontynuowało, lecz także rozszerzało zakres swojej działalności. W 1896 r. zarząd Towarzystwa Dobroczynności z myślą o rozwoju wychowaw-

${ }^{55}$ Po rosyjsku: „Dom trudoljubija”. Niekiedy tego typu placówki nazywano w języku polskim „domami rzemiosł”. Por. Hankowska, Kościót św. Katarzyny, s. 243.

${ }^{56}$ Rutkowski, Biskup Antoni Malecki 1861-1935, Warszawa 1935, s. 26.

${ }^{57}$ ACSM, Seria E. II. t. 2, Zakrzewska, Historia Zgromadzenia, s. 74-75. Do 1895 r. jego opiekunami Domu Pracy byli panowie Houwald i Święcicki, później dziekan petersburski, proboszcz kościoła św. Katarzyny, ks. Wincenty Świderski oraz wdowa generała, p. Karłowicz. Jednakże gospodarzem i opiekunem domu pozostawał w czasie wielu lat R. Sendziuk. W 1896 r. w Domu Pracy pracowały 72 kobiety. W 1896 r. Dom pracy otrzymał pozwolenie na nabycie innego pomieszczenia przy ul. Kanonierskiej 6. Oprócz możliwości pracy korzystający z niego mieli możliwość korzystania z tanich obiadów po 5 kopiejek. Por. Hankowska, Kościót, s. 243. W późniejszym czasie Dom Pracy został wyposażony w nowoczesną pralnię i szwalnię oraz pomieścił się w nim sierociniec dla dziewczynek. Por. „25-letni jubileusz rz.-kat. Towarz. Dobroczynności”, w: „Dodatek ilustrowany do nru 140 «Dziennika Petersburskiego»" z 1909 r., s. 2.

${ }^{58}$ Hankowska, Kościót, s. 243. Początkowo była ona placówką deficytową. W stołówce wydawano ok. 400 obiadów dziennie, w 1898 г. - 454, в 1899 r. - 473. Kuchnia studencka potrzebowała stałej pomocy finansowej od zarządu Towarzystwa. Jednakże już ok. 1902 r. prawie na siebie zarabiała. Por. „25-letni jubileusz rz.-kat. Towarz. Dobroczynności”, w: „Dodatek ilustrowany do nru 140 «Dziennika Petersburskiego»” z 1909 r., s. 3; Por. także: Ptaszycki, Z moich wspomnień, w: Z murów św. Katarzyny, s. 57; L. Bazylow podaje, że inicjatywę utworzenia Kuchni Studenckiej podał już w 1869 Gustaw Kamieński (1848-1930), pierwszy prezes Koła Inżynierów Technologów Petersburskich. Por. Bazylow, Polacy w Petersburgu, s. 323. 
czych zakładów ks. Maleckiego nabył dużą posiadłość z domem i placem przy ul. Kiriłłowskiej 19. Chociaż posiadłość była zadłużona na sumę 50 tys. rubli, to jednak komisja Towarzystwa Dobroczynności w składzie Gen. L. Jocher, płk. Kolankowski, arch. Ryłło i kpt. Szolkowski uznała, że warunki kupna są odpowiednie dla zakładu. Plac liczył 2400 sążni kwadratowych, posiadał dom i kilka budynków drewnianych. Koszty odnowienia domu, budynków i wzniesienia kaplicy wynosiły 30 tys. rubli, z czego 4.500 rubli wydzieliła administracja kościoła św. Katarzyny, resztę powinien zebrać sam ks. Malecki. W budynkach urządzono stolarnię, introligatornię, warsztaty ślusarski i kowalski ${ }^{59}$. Już w październiku bp A. Symon poświęcił tam kaplicę $e^{60}$.

Z funduszu pomocy dla uczącej się młodzieży w 1896 r. skorzystały 192 osoby. Sposobem powiększania tego funduszu było urządzanie spektakli, koncertów i innych imprez. Natomiast fundusz dla studentów wspierał stałą pomocą 15 studentów, a 104 osobom udzielono pomocy doraźnej. Komitet poszukiwania pracy na 324 podania mógł zaproponować 91 miejsc pracy. W przytułku św. Maryi przebywało 3 mężczyzn i 33 kobiety ${ }^{61}$.

Wcześniej wspomnieliśmy o powstaniu sierocińca Fichtnera dla chłopców niemieckiego pochodzenia, który nie korzystał z opieki Towarzystwa Dobroczynności, chociaż podlegał administracji kościoła św. Katarzyny. Pracujący przy kościele kapłani Austriacy dążyli do tego, aby dobroczynność nie podlegała polskiemu kierownictwu. Dominikanin, o. J. Schump postanowił utworzyć sierociniec dla dziewczynek różnych narodowości. Nazwał go z francuska „Międzynarodowym azylem". Powstał on w 1896 i mieścił się początkowo w Petersburgu przy ul. Nabiereżnaja reki Karpowki nr 6. Początkowo znajdował się on pod opieką Towarzystwa Dobroczynności przy kościele św. Katarzyny oraz dam z wyższych sfer petersburskiego towarzystwa, zwłaszcza żon ambasadorów niemieckich i austriackich. W sierocińcu przebywało 16 dziewczynek. Rolę honorowej opiekunki sierocińca zarząd Towarzystwa Dobroczynności przy kościele św. Katarzyny powierzył 15 listopada 1897 r. księżnej Radolin-Radolińskiej, żonie ambasadora niemieckiego ${ }^{62}$. Później ten sierociniec został przeniesiony do domu, zakupionego przez Towarzystwo Dobroczynności od generała Wojnickiego w podmiejskiej wsi Szuwałowo. Wtedy to o. J. Schump, chcąc uniezależnić się od Towarzystwa Dobroczynności, które uważał za „polskie”, stworzył odrębne „Międzynarodowe Towarzystwo opieki nad biednymi i chorymi dziewczętami-sierotami katolicz-

${ }^{59}$ A. Woycicki, Zakłady wychowawcze ks. Maleckiego w Piotrogrodzie, w: „Polski Kalendarz Piotrogrodzki na 1917 r.", s. 158-1159.

${ }^{60}$ ACSM, Seria E. II. t. 2, Zakrzewska, Historia Zgromadzenia, s. 72; 17 maja 1899 r. postanowiono rozbudować zakład, a już 1 grudnia przeniesiono go do nowego budynku. Zakład stał się nową fabryką-szkołą, zatrudniającą do 60 wykwalifikowanych robotników i przygotowującą uczniów do pracy zawodowej z dyplomem czeladnika. Por. Woycicki, Zakłady wychowawcze, w: „Polski Kalendarz Piotrogrodzki na 1917 r.”, s. 160.

${ }^{61}$ Hankowska, Kościół, s. 243.

${ }^{62}$ Tamże, s. 242-243. 
kami”, które miało podjać się utrzymywania sierocińca. O pracy w sierocińcu zaprosił francuskie siostry św. Józefa z Chambéry ${ }^{63}$.

W 1899 r. w setną rocznicę urodzin Adama Mickiewicza, Konrad Niedźwiecki zainicjował obok istniejącego od lat Komitetu zarządzającego specjalnym funduszem dla biednych studentów oraz Koła pomocy uczącej się młodzieży, stworzenie w Towarzystwie Dobroczynności funduszu imienia A. Mickiewicza w wysokości 10 tys. rubli, z którego procenty przeznaczano na stypendia dla biednej uczącej się młodzieży ${ }^{64}$. Była to więc jedynie nowa forma, gdyż Towarzystwo od samego początku swojego istnienia wspierało uczącą się młodzież. W Komitecie poszukiwania pracy działali $\mathrm{m}$. in. dyrektor Zakładów Putiłowskich Ignacy Jasiukiewicz ${ }^{65}$ i profesor Instytutu Leśnego Aleksander Rudzki ${ }^{66}$.

Towarzystwo Dobroczynności utrzymywało przytułek dla starców św. Maryi. W 1901 r. pomagało w utrzymaniu mieszkających tam 45 starych osób. W przeniesionych do nowych pomieszczeń zakładów ks. Maleckiego utrzymywało 121 chłopców i wspierało rozwijający się sierociniec za Narwską Bramą ${ }^{67}$. Towarzystwo utrzymywało nadal Dom Pracy, w którym trudziło się 280 kobiet dorosłych i 32 dziewczyny. $Z$ matkami przychodziło 25 dzieci, które podczas pracy matek, miały zapewnioną opiekę. W ciagu roku wydano tam 2388 obiadów. W Domu Pracy działała pracownia krawiecka i pralnia, własnością domu była też krowa, prawdopodobnie z myślą o dzieciach. W sierocińcu Rodziny Maryi (ouvroir) wspierano 46 dziewcząt i jedną staruszkę. W taniej studenckiej stołówce wydano w 1901 r. 9874 obiady. W internacie przy kościele św. Katarzyny Towarzystwo utrzymywało 12 dziewczynek, spośród których 6 wysłano na kolonie letnie. Nową inicjatywą Towarzystwa Dobroczynności było zorganizowanie grupę ok. 50 lekarzy, którzy zobowiązali się przyjmować biednych bezpłatnie ${ }^{68}$.

${ }^{63}$ RGIA, F. 821, op. 128, d. 181, Tajnye r.-k. prîuty, monastyrii i monašeskie organizacii, 1. 1b2 odwr., Direktor DDDII A. H. Haruzin - Zuevu N. P. 6 IV 1911.

${ }^{64}$ „25-letni jubileusz rz.-kat. Towarz. Dobroczynności”, w: „Dodatek ilustrowany do nru 140 «Dziennika Petersburskiego» z 1909 r., s. 3.

${ }^{65}$ Jasiukowicz Ignacy (1847-1914), główny inżynier i dyrektor techniczny Newskiej Fabryki Parowozów i Okrętów, w 1884-1888 dyrektor Zakładów Putiłowskich. Por. Bazylow, Polacy w Petersburgu, s. 327.

${ }^{66}$ Komitet poszukiwania pracy przy Towarzystwie Dobroczynności od początku swojego istnienia do 1902 r. pomógł znaleźć pracę 446 osobom. Por. S. Šulc,ml., Hramy Sankt-Peterburga. Istoria i sovremennost', Sankt-Peterburg 1994, s. 237. Prof. A. Rudzki ur. 1837 na Wołyniu. W 1857 ukończył Instytut Leśny w Petersburgu. Od 1880 r. profesor Instytutu. W latach 1891-1895 będąc syndykiem w administracji kościoła św. Katarzyny, zdołał przeforsować szereg reform i remontów zabudowań kościelnych, dzięki którym powstały dogodne warunki do funkcjonowania szkół. Por. L. Śliwiński, Reformy prof. A. Rudzkiego w latach 1891-1895, w: Z murów św. Katarzyny, s. 215-220 .

${ }^{67}$ Piszemy o nim poniżej.

${ }^{68}$ Otčët pravleniâ rimsko-katoličeskogo Blagotvoritelnogo obŝestva (učreždënnogo v 1884 g.) pri cerkvi Sv. Ekateriny v S.-Peterburge za 1 ânvarâ 1901 - 1 ânvarâ 1902, S.-Peterburg 1902, s. 43-48. Oficjalnie nosiło ono nazwę: Opieka lekarska przy Rzymskokatolickim Towarzystwie Dobroczynności”. Por.. Bazylow, Polacy w Petersburgu, s. 387. 
W 1902 r. Towarzystwo Dobroczynności kontynuowało zadania z ubiegłego roku. Funkcjonowała fundacja szkół średnich oraz komitet opiekuńczy dla uczącej się młodzieży ${ }^{69}$. W sprawozdaniach z następnych lat odnotowano, że oprócz poprzednich zobowiązań, Towarzystwo pomagało też zorganizować kolonie letnie dla dzieci. W 1905 r. dzięki pomocy Towarzystwa na stacji Wierebia w guberni nowgorodzkiej przebywało na kolonii 62 dzieci w okresie od 29 maja do 10 sierpnia $^{70}$.

Sprawozdania z działalności Towarzystwa Dobroczynności w pierwszych latach XX w. mówią też o nowej placówce, którą ono wspierało. Był to sierociniec, powstały w 1898 r. w dzielnicy robotniczej za tzw. Narwską Bramą Triumfalną, gdzie powstała potężna fabryka przemysłu metalowego, tzw. Putiłowskie zakłady. W fabryce znalazło pracę wielu katolików, zwłaszcza Polaków. Mieszkało tam wiele rodzin biednych, dlatego potrzebna tam była zarówno świątynia katolicka, jak i zakłady dobroczynno-wychowawcze, które pełniłyby jednocześnie funkcję sierocińca, szkółki parafialnej i ośrodka duszpasterskiego. Ten nowy ośrodek początkowo wspierało materialnie Towarzystwo Dobroczynności przy kościele św. Katarzyny. Jednakże niektórzy działacze i dobrodzieje zrozumieli, że należy powołać tam odrębną organizację. Taką funkcję zaczął pełnić Komitet budowy sierocińca ${ }^{71}$.

W drugim okresie działalności Towarzystwa Dobroczynności zachodziły częstsze zmiany na stanowisku prezesa zarządu. Od 1895 do 1898 r. prezesem był inicjator założenia Towarzystwa Dobroczynności, senator Gartkiewicz. Od 1898 do 1900 r. prezesem był generał A. Jocher, potem do 1902 r. znowu Karol Gartkiewicz. Od 1902 r. urząd prezesa sprawował S. Jastrzębski ${ }^{72}$

${ }^{69}$ Otčët pravleniâ rimsko-katoličeskogo Blagotvoritelnogo obŝestva (učreždënnogo v 1884 g.) pri cerkvi Sv. Ekateriny v S.-Peterburge za 1 ânvarâ 1902 - 1 ânvarâ 1903, S.-Peterburg 1903, s. 103.

${ }^{70}$ Otčët pravleniâ rimsko-katoličeskogo Blagotvoritelnogo obŝestva (učreždënnogo v $1884 \mathrm{~g}$.) pri cerkvi Sv. Ekateriny v S.-Peterburge za 1 ânvarâ 1905 - 1 ânvarâ 1906, S.-Peterburg 1906, s. 106.

${ }^{71}$ W 1903 r. kapelanem sierocińca i kaplicy był ks. Wincenty Czeczot. Budowany przy sierocińcu drewniany kościół stał się on centrum nowej ponad 10-tysięcznej parafii św. Kazimierza. Na początku 1903 r. było w sierocińcu 25 chłopców i 32 dziewczynki na całkowitym utrzymaniu. Z tej sumy do rodzin lub na służbę poszło 8 chłopców i 12 dziewczynek, a przybyło 17 chłopców i 12 dziewczynek, więc na początku 1904 r. było 34 chłopców i 32 dziewczynki w wieku od 5 do 16 lat. Ponadto 156 dzieci przybywało na naukę religii do sierocińca i pozostawało tam w godz. 9.0013.00. Z bezpłatnego obiadu korzystało 110 dzieci, tzn. znacznie więcej niż mieszkańców sierocińca. Dziewczynki w sierocińcu uczyły się szycia i pończosznictwa a chłopcy szewstwa. O zdrowie dzieci troszczył się lekarz z Komitetu i lekarze z Zakładów Putiłowskich. Ofiary na utrzymanie sierocińca zbierali także robotnicy w fabryce. Przyjmowano też dary w naturze, hodowano prosięta i cielęta na sprzedaż. Por. „Otčot ubežiŝa dlâ prizreniâ maloletnih detej obojego pola p.-kat. veroispovedaniâ v S.-Peterburge za Narvskoj Zastavoj po Ušakovskoj 20, Sankt-Peterburg 1904.

72 „25-letni jubileusz rz.-kat. Towarz. Dobroczynności”, w: „Dodatek ilustrowany do nru 140 «Dziennika Petersburskiego»" z 1909 r., s. 4. 


\section{c) kontynuacja i nowe inicjatywy trzeciego dziesięciolecia (1904-1914)}

Rozwijające się zakłady ks. Maleckiego w 1905 r. utworzyły swój oddział w Łudze pod Petersburgiem, dokąd przeniesiono chłopców w wieku 2-10 lat. Na ten ośrodek sumę 40 tys. rubli ofiarował Władysław Bilski, dlatego nazwano go „Władysławówką”. Posiadał on kaplicę, boisko do zabaw, pralnię, łaźnie itp. Tam mogli przebywać też chłopcy o słabszym zdrowiu aż do 14 roku życia, a potem kierowani byli do zakładów rzemieślniczych ${ }^{73}$. „Władysławówka” był to kompleks drewnianych domów mieszkalnych i budynków gospodarczych z kaplicą i boiskiem do gier. Zakład znajdował się na terenie falistym, otoczony był sosnowym lasem. Siostry sercanki pracowały tam jako wychowawczynie i nauczyciel$\mathrm{ki}^{74}$. Podobnie jak wiele innych placówek charytatywnych, także i ten zakład, finansowo wspierało Towarzystwo Dobroczynności przy kościele św. Katarzyny ${ }^{75}$.

Chociaż Szkoła Elementarna dla dziewcząt przy kościele św. Katarzyny istniała już od wielu lat, taką szkołę dla chłopców utworzono dopiero w $1906 \mathrm{r}$. w związku z reorganizacją Szkoły męskiej w Gimnazjum Męskie. Wcześniej istniejąca klasa przygotowawcza została przekształcona w osobną placówkę: 2-klasową szkołę elementarną. Każda klasa miała 2 oddziały ${ }^{76}$.

W 1906 r. ks. Malecki otworzył w swoim zakładzie przy ul. Kiriłłowskiej tzw. Szkołę Polską, formalnie 2-klasową, a w rzeczywistości z programem progimnazjum. Zakłady posiadały dwa wydziały: szkolny i rzemieślniczy ze swoimi internatami. W szkolnym byli chłopcy, uczęszczający do progimnazjum na miejscu lub do gimnazjum przy kościele św. Katarzyny. W rzemieślniczym chłopcy powyżej 14 lat uczyli się różnych zawodów. Ok. 100 uczniów mieszkało w internacie i uczyło się na koszt Towarzystwa Dobroczynności, pozostali płacili za naukę 200 rubli rocznie ${ }^{77}$. W 1906 r. Towarzystwo Dobroczynności zorganizowało letnią kolonię dla dzieci na Litwie w miejscowości Rozwalino pod Poniewieżem ${ }^{78}$.

Chociaż powstanie nowej parafii św. Kazimierza wzięło swój początek od sierocińca dla dzieci, utrzymywanego początkowo przez Towarzystwo Dobroczynności, to jednak wkrótce stała się ona inicjatorką nowych działań. Pracujący od 1908 r. jako proboszcz przy kościele św. Kazimierza ks. Antoni Około-Kułak pragnął utworzyć tam towarzystwo dla katolickich robotników. Udało się zare-

${ }^{73}$ Woycicki, Zakłady wychowawcze, w: „Polski Kalendarz Piotrogrodzki na 1917 r.”, s. 161; ACSM, Seria E. II. t. 2, Zakrzewska, Historia Zgromadzenia, s. 77; R. Dzwonkowski, Losy duchowienstwa katolickiego w ZSSR. 1917-1939. Martyrologium, Lublin, 1998., s. 341-347.

${ }^{74}$ ACSM, Seria E. II. t. 2, Zakrzewska, Historia Zgromadzenia, s. 77; Dzwonkowski, Losy duchowienstwa katolickiego w ZSSR, s. 341-347.

${ }^{75}$ RGIA, f. 821, op. 125, d. 3030 - R-k. blagotvoritelnye i religiozno-prosvetitelskie obŝestva, 1. 64-64 odwr. - SPb gubernator - Ministru VD 20 VII 1909; Tamże, 1.88 - Gl. Upravlenie po delam - v DDDII 5 VI 1910.

${ }^{76}$ O. Opólska, Szkoła Elementarna, w: Z murów św. Katarzyny, s. 249-251.

${ }^{77}$ Katolik nad Newa, ,Kalendarz rz.-katolicki «Pod znakiem Krzyża»” na rok 1912, s. 75.

${ }^{78}$ Otčët pravleniâ rimsko-katoličeskogo Blagotvoritelnogo obŝestva (učreždënnogo v 1884 g.) pri cerkvi Sv. Ekateriny v S.-Peterburge za 1 ânvarâ 1906 - 1 ânvarâ 1907, S.-Peterburg 1907, s. 112. 
jestrować Katolickie Towarzystwo Pomocy Wzajemnej ${ }^{79}$. Sierociniec istniejący przy kościele św. Kazimierza, określany jako sierociniec-żłobek, w dalszym ciagu w pewnym zakresie, jak i inne nie będące jego własnością placówki, wspierało Towarzystwo Dobroczynności przy kościele św. Katarzyny ${ }^{80}$.

W 1907-1908 r. pojawiła się nowa w Petersburgu forma zorganizowania pracy dobroczynnej. Były to tzw. Konferencje św. Wincentego à Paulo ${ }^{81}$.

W 1909 r. prezesem zarządu Towarzystwa Dobroczynności został gen. Antoni Risenkampf. W 1910 r. członkami zarządu byli: ks. K. Budkiewicz, proboszcz kościoła św. Katarzyny, Leopold Czechowicz, Konrad Niedźwiecki, Michał Kierbedź, Maria Poklewska-Koziełł, Franciszek Piekarski, Stanisław Malecki. Komisję rewizyjną stanowili: J. Jacyna, S. Jabłoński, A. Babiański i W. Kopański. Członków honorowych zaszczyconych tą godnością za szczególne zasługi było 13, członków honorowych, którzy wnieśli jednorazową ofiarę przynajmniej 100 rubli było 108 , członków rzeczywistych $-252^{82}$.

W sprawozdaniu za 1910 r. Towarzystwo Dobroczynności przy kościele św. Katarzyny podawało, że posiada na własność 3 domy, to znaczy dom przy ul. Kiryłłowskiej 19, gdzie znajdował się sierociniec dla 150 chłopców, którego wartość oceniano na sumę 125.354 ruble, dom starców na Wyborskiej Stronie - 13.622 ruble i Dom Pracy przy ul. Kanonierskiej $6-30.695$ rub. Ponadto własnościa Towarzystwa były umieszczone w bankach papiery wartościowe. Majątek łącznie oceniano na sumę 409.814 rub. 7 kop. ${ }^{83}$.

Z sumy rozchodu, który w 1910 r. wynosił 194.493 rub. 46 kop., na cele ogólne wydano 28.639 rub. 57 kop., na co składały się zapomogi jednorazowe, zapomogi wypłacane co miesiąc, wsparcie 44 osób z okazji Wielkanocy, koszta administracji zarządu, pokrycie długu z poprzednich lat (18.573 rub. 65 kop.)

${ }^{79}$ W Departamencie Spraw Duchownych obcych wyznań zwrócono uwagę na to, że zarejestrowane Towarzystwo Pomocy Wzajemnej, które miało wspierać dobroczynne instytucje w parafii św. Kazimierza, oprócz celów dobroczynnych, stawiało sobie także cele religijno-oświatowe, gdyż jeden z paragrafów statutu mówił o otwieraniu przez Towarzystwo rzymskokatolickich konfesyjnych szkół. Ponieważ, zgodnie ze statutem, działalność Towarzystwa miała obejmować całą Rosję, w ten sposób, jak zauważył urzędnik departamentu, zalegalizowano by jego prawo do otwierania szkół także w Królestwie Polskim. Departament Spraw Duchownych Wyznań Obcych, przekazał to zastrzeżenie ministrowi spraw wewnętrznych Piotrowi Stołypinowi, ten 14 czerwca 1910 r. zażądał od burmistrza Petersburga ponownego rozpatrzenia prawidłowości rejestracji jego statutu. Prawdopodobnie zostało ono rozwiązane. Por. RGIA, F. 821, op. 125, d. 3030 - R-k. blagotvoritelnye i religiozno-prosvetitelnye obŝestva, 1.2 - obozrenie pečati.

${ }^{80}$ „Otčot ubežisia dlâ prizreniâ maloletnih detej obojego pola p.-kat. veroispovedaniâ $v$ S.-Peterburge za Narvskoj Zastavoj po Ušakovskoj 20, Sankt-Peterburg 1904.

${ }^{81}$ Główną różnicę między Towarzystwem Dobroczynności i Konferencjami stanowiło to, że w Towarzystwie na ogół zamożni ludzie organizowali pomoc dla mniej zamożnych, a Konferencje angażowały zwyczajnych parafian, którzy próbowali zaradzić konkretnym potrzebom osób mieszkających po sąsiedzku. Jednakże ze względu na wymagania władz i na inne potrzeby, Konferencje przekształciły się w nowe Towarzystwo Dobroczynności. Por. Towarzystwo św. Wincentego à Paulo w Petersburgu, „Wiadomości Archidiecezjalne”, 2 (1909) kol. 18.

${ }^{82}$ Katolik nad Newa, Kalendarz rz.-katolicki „«Pod znakiem Krzyża»” na rok 1912, s. 73.

${ }^{83}$ Tamże, s. 74. 
i inne wydatki. Wsparcia jednorazowe, miesięczne i okazyjne pochłaniały obecnie zaledwie $2 \%$ rocznego dochodu Towarzystwa, co stanowiło istotną zmianę w stosunku do pierwszych lat istnienia organizacji. Koszta administracyjne pochłaniały mniej niż $1 \%$ dochodu. Było to możliwe, ponieważ cały zarząd pracował bezpłatnie. Największą sumę wydawano na utrzymanie domu dla chłopców przy ul. Kiryłłowskiej 19 - ok. 40.000 rubli. Pomoc Towarzystwa dla domu przy ul. Kiriłłowskiej polegała na pokrywaniu kosztów utrzymaniu chłopców, opłacie podatków, opłacie ubezpieczeń, przeprowadzaniu remontów. Znacznie mniejsze sumy Towarzystwa przeznaczało na dom starców na Wyborskiej Stronie, gdzie przebywało od 33 do 40 osób (niespełna 6 tys. rubli) i na sierociniec przy kościele św. Kazimierza (6.350 rub.). Natomiast na sierociniec Rodziny Maryi na Wyspie Wasilewskiej („ouvroir”), gdzie przebywało ponad 50 dziewcząt i grupa staruszek, a także istniała szkoła, Towarzystwo przeznaczało zaledwie 3.189 rub. i dodatkowo - 2 tys. rubli, jako pomoc dla komitetu, opiekującego się zakładem ${ }^{84}$. Wynika to stąd, że Rodzina Maryi, jako instytucja istniejąca od lat, wypracowała sobie sposób utrzymania, wykorzystując pracę wychowanek i dochody z podmiejskiego gospodarstwa rolnego Mikołajówka, gdzie też pracowały siostry i wychowanki ${ }^{85}$.

Towarzystwo Dobroczynności przy kościele św. Katarzyny wydzielało także środki na stypendia dla biednych uczniów (prawie 10 tys. rubli) ${ }^{86}$, na utrzymanie Szkoły Elementarnej przy kościele św. Katarzyny -4 tys. rubli i na utrzymanie sierocińca, założonego przez Koło Pań - ponad 7 tys. rubli. Sporo, bo ponad 12 tys. kosztował Dom Pracy z pralnia, szwalnią i tanimi obiadami oraz jego administracja, ubezpieczenie, podatki itp. Na sierociniec, który nazwano „Jasełka” (prawdopodobnie chodzi o żłóbek dla małych dzieci) - ponad 2 tys. rubli. Nieustannie wzrastały kapitały w papierach wartościowych. Zapisy w procentowych papierach od zmarłych osób wynosiły ponad 100 tys. rubli. Przeznaczono je na zwiększenie funduszu na cele pomocy uczącej się młodzieży ${ }^{87}$.

W 1909 r. zostało zarejestrowane przez kancelarię petersburskiego burmistrza Towarzystwo Dobroczynności przy kościele Nawiedzenia NMP na Wyborskiej Stronie. Jednakże wkrótce ministerstwo spraw wewnętrznych zażądało bądź rozwiązania go, bądź przepracowania statutu. Przyczyną tego było umieszczenie wśród statutowych zadań, oprócz celów charytatywnych, także celów oświatowych. DDDII zażądał usunięcia ze statutu zapisu o tym, że przewodniczącym

${ }^{84}$ Tamże.

${ }^{85}$ Rodzina Maryi w ciagu lat swojego istnienia wypracowała sposoby zdobycia środków i sposoby działania. Otworzyła w wielu miejscowościach swoje placówki, których sprawa własności były skomplikowana. Niektóre należały do Komitetu opiekuńczego, inne były zapisane na osoby prywatne. Por. Archiwum Rodziny Maryi w Warszawie (ARMW), Sygn. F-f-8, Notatki s. Teresy Helman, mps., s. 38-39.

${ }^{86}$ Ostatni dyrektor Gimnazjum Męskiego S. Cybulski, nie zaznaczając roku, którego wiadomość dotyczy, wymienił sumy 11 stypendiów, które otrzymywali uczniowie gimnazjum od Towarzystwa Dobroczynności. W sumie było to 1.340 rubli rocznie. Por. Cybulski, Gimnazjum przy kościele św. Katarzyny w Petersburgu, w: Z murów św. Katarzyny, s. 241.

${ }^{87}$ Katolik nad Newq, Kalendarz rz.-katolicki „Pod znakiem Krzyża” na rok 1912, s. 74. 
Towarzystwa jest proboszcz parafii. Ponadto postawiono wymóg usunięcia ze statutu słów o zależności towarzystwa od władzy diecezjalnej, o prawie zakładaniu i utrzymaniu szkół, o wspieraniu kółek kulturalno-umoralniających. Dodano wymóg, aby organizacja zdawała sprawozdania burmistrzowi i ministrowi spraw wewnętrznych. Po przeprowadzeniu takich zmian 5 września 1911 r. ministerstwo zarejestrowało towarzystwo, którego działalność ograniczała się do parafii na Wyborskim Cmentarzu ${ }^{88}$.

W 1912 r. Michał Kierbedź, syn budowniczego mostu przez Newę, Stanisława Kierbedzia, ofiarował zakładom ks. Maleckiego ogromną sumę 165.000 rubli, za którą był wybudowany 4-piętrowy dom przy ul. Kiryłłowskiej. Jego budowniczym był Marian Peretiakowicz, który swoją pracę wykonywał bezinteresownie. Gmach, nazwany „domem Kierbedzia”, został otwarty 30 października 1913 r. W mieszczącej się tam dużej auli odbywały się różne przedstawienia kulturalne i dobroczynne ${ }^{89}$. Wtedy też do zakładów ks. Maleckiego został także przeniesiony sierociniec dla dziewcząt, prowadzony przez Koło Pań ${ }^{90}$.

Ponieważ w 1913 r. władze państwowe zamknęły francuski sierociniec „Dobrego Pasterza", jego majątek przyjęło Towarzystwo Dobroczynności przy kościele św. Katarzyny. Opiekowało się ono także dwoma nowymi placówkami, które określono jako „Sierociniec-żłobek”11. 11 grudnia 1913 r. zarząd Petersburskiego Towarzystwa Dobroczynności poprosił gubernatora o zgodę na urządzanie w celu charytatywnym koncertów w auli niedawno zbudowanego przy ul. Kiryłłowskiej domu sierocińca dla chłopców, jednakże władze na to się nie zgodziły, podając jako jedyną motywację odmowy to, że sala w „Domu Kierbedzia” znajduje się na 4 piętrze $^{92}$.

W 1913 r. pojawiło się w Towarzystwie Dobroczynności nowe Koło, które nazwano Towarzystwem Ochrony Kobiet. Chodziło jemu o ochronę kobiet narażonych na demoralizację i o podniesienie oświaty kobiet. Ilość członków Towarzystwa Dobroczynności utrzymywała się na poprzednim poziomie (rzeczywistych członków w 1914 r. było 189). Towarzystwo zbierało ofiary w kościołach i w dalszym ciagu korzystało z procentów od wcześniej złożonych ofiar i zapisów. Ponosiło też koszty utrzymania rodziny Liniewiczów, która zapisała jemu kilka domów. Były to budynki przy ulicy Nabiereżnaja reki Fantanki nr 61-63 i 67 oraz

${ }^{88}$ RGIA, F. 821, o. 128, d. 47 - R-k. blagotvoritelnye obŝestva, č. I., 1. 350-362 odwr. - Ustav Prosvetitelno-Blagotvoritelnogo Obŝestva PDM v g. Sankt_Peterburge, ul. Arsenalnaâ 8.

${ }^{89} \mathrm{Z}$ tego zakładu wyszedł późniejszy apostoł studentów w Warszawie, ks. Szwejnic. Por. ACSM, D III, t. 2, Wspomnienia sióstr z Petersburga, s. 77.

${ }^{90}$ Sprawozdanie z działalności Kótka Pań za 1912 r., Petersburg, [1913]. s. 1-4.

${ }^{91}$ Otčët pravleniâ rimsko-katoličeskogo Blagotvoritelnogo obŝestva (učreždënnogo v 1884 g.) pri cerkvi Sv. Ekateriny v S.-Peterburge za 1 ânvarâ 1913 - 1 ânvarâ 1914, S.-Peterburg 1914, s. 26-27. Tego punktu nie ma w poprzednich sprawozdaniach, np. w cytowanym przez nas „Dodatku ilustrowanym” podano, że w 1905 r. stworzono z inicjatywy p. Bielskiej „Jasełka”, nie określając bliżej, o jaką instytucję chodzi. Por. „25-letni jubileusz rz.-kat. Towarz. Dobroczynności”, w: „Dodatek ilustrowany do nru 140 «Dziennika Petersburskiego»" z 1909 r., s. 3.

${ }^{92}$ Centralnyj Gosudarstvennyj Istoričeskij Arhiv Sankt-Peterburga (CGIA SPb), F. 569, op. 15, d. 1021 - Pravlenie - Gubernatoru 11 XII 1913. 
dom przy Bolszoj Linii rynku Apraksina. Można było więc wynajmować w nich mieszkania, piwnice i magazyny, aby w ten sposób zdobyć środki na rozszerzenie działalności dobroczynnej. $Z$ dochodów spłacano dług, utrzymywano rodzinę ofiarodawców oraz korzystano na pokrycie kosztów działania placówek charytatywnych ${ }^{93}$.

Tak, jak i w poprzednich latach, największe sumy Towarzystwo Dobroczynności wydzielało na utrzymanie sierocińca dla chłopców, tzn. zakładów ks. Maleckiego (chłopców było tam od 142 do 149), jakkolwiek zakłady te znaczny procent kosztów utrzymania pokrywały we własnym zakresie. W przejętym przez Towarzystwo sierocińcu „Dobrego Pasterza” w 1914 r. pojawiły się na utrzymaniu dzieci. W dalszym ciagu działał fundusz pomocy dla młodzieży uczącej się w szkołach wyższych. Kolonie letnie dla dzieci, tym razem zorganizowano w Carskim Siole. Wśród dochodów Towarzystwa coraz więcej było celowych ofiar. Bogaci ofiarodawcy zapisywali określoną sumę, procenty od której, miały być przeznaczane na określony cel, np. na stypendium dla konkretnych uczących się osób. Pewna osoba zapisała znaczną sumę na zakłady ks. Maleckiego w zamian za dożywocie w nich ${ }^{94}$.

\section{d) Koło Pań (1900-1918)}

Zorganizowana przy kościele św. Katarzyny Szkoła Elementarna nie należała do Towarzystwa Dobroczynności, lecz ponieważ zajmowała się praktycznie bezpłatnym, podstawowym uczeniem biednych dzieci, była placówką dobroczynną i potrzebowała stałej pomocy. Aby zaradzić temu, nauczycielki szkół przy kościele i bogatsze obywatelki utworzyły w 1900 r. „Koło Pań dla pomocy uczniom Szkoły Elementarnej". Wchodziły w nie osoby związane z działaczami Towarzystwa Dobroczynności, niejednokrotnie ich żony. Koło Pań, idąc z duchem czasu, rozszerzało pole swojej działalności. Prowadziło własne rachunki, chociaż właściwie należało do Towarzystwa Dobroczynności. Panie początkowo postanowiły zorganizować sierociniec dla 30 dziewczynek, a w 1902 r. zorganizowały wyjazd na kolonie letnie dla 66 dziewczynek ze Szkoły Elementarnej. W czasie pobytu na kolonii dzieci uczyły się prac ręcznych. W 1903 r. Koło Pań liczyło już 119 członkiń rzeczywistych, a także pewną grupę członków honorowych, wśród których był ks. kan. Erazm Kluczewski i ks. Ignacy Czajewski. Fundusze, zbierane przez Koło, przeznaczane były na opłacanie lokalu sierocińca, na wynagrodzenie dla personelu, na wyżywienie i ubranie dla dzieci, na książki i na pomoc dla biedniejszych dzieci oraz na zorganizowanie różnych uroczystości dla dzieci ${ }^{95}$.

${ }^{93}$ Por. Otčët po upravleniju imuŝestvom L. O. Lineviča za 1914 g., Piotrogrod 1915, s. 1-6.

${ }^{94}$ XXX Otčët pravleniâ rimsko-katoličeskogo Blagotvoritelnogo obŝestva (učreždënnogo v 1884 g.) pri cerkvi Sv. Ekateriny v S.-Peterburge za 1 ânvarâ 1914 - 1 ânvarâ 1915, S.-Peterburg 1906, s. $5-41$.

${ }^{55}$ Otčët deâtelnosti Damskogo kružka dlâ pomoŝi učenicam elementarnoj školy, Sankt-Peterburg 1903, s. 1-4. 
W 1906 r. przewodnicząca „Koła” została Maria Poklewska-Koziełł, czyli żona znanego fabrykanta i wybitnego działacza w zakresie dobroczynności. Utrzymywany przez Koło Pań sierociniec znajdował się przy ul. Wielkiej Puszkarskiej 7. W 1906 r. dziewczynki-sieroty, uczęszczające dotychczas do Szkoły Elementarnej św. Katarzyny, zostały przeniesione do niedawno powstałej prywatnej szkoły p. Rosnowskiej, do niej zostały przeniesione. W sierocińcu, utrzymywanym przez Koło, dziewczynki miały 2 godziny nauki szycia oraz zapewniona opiekę medyczną i dentystyczną. Było tam 55 dziewczynek, spośród których 47 chodziło do szkoły elementarnej, 3 do żeńskiej szkoły św. Katarzyny, 5 na naukę szycia. Ze względów pedagogicznych postanowiono przenieść 3 dziewczynki do internatu przy kościele św. Katarzyny, a 2 stypendystki ks. Franciszka Buczysa do „ouvroir” na 14 linii Wyspy Wasilewskiej.

Koło Pań w 1906 r. urządziło 2 imprezy dla dzieci: wigilię dla sierot oraz choinkę z nagrodami dla 100 dziewczynek. Panie zbierały się nie tylko, aby dyskutować sprawy finansowe i organizacyjne. Dyskutowały także o metodach wychowawczych. W 1906 r. podjęły postanowienie, aby w procesie wychowawczym były zniesione kary, a w to miejsce wprowadzone metody zachęty w postaci nagród dla bardziej pilnych dzieci. W czasie uroczystości nagrodzono 8 dziewczynek książkami ufundowanymi przez p. Poklewską-Koziełł. Latem Koło zorganizowało we wsi Wyra niedaleko od Siewierskiej ${ }^{96}$ kolonie dla 175 dzieci, wśród których było 50 dziewczynek z sierocińca ${ }^{97}$.

Nie dysponujemy sprawozdaniami z następnych lat (nie wiemy, czy były drukowane), lecz porównanie sprawozdania z 1906 r. i 1912 pozwala na stwierdzenie, że Koło Pań kontynuowało podjęte inicjatywy w ciagu kolejnych lat. W 1912 r. Koło Pań opiekowało się nadal sierocińcem, w którym przebywało 60 dziewczynek. Spośród nich 46 uczęszczało do szkoły elementarnej, a po lekcjach uczyło się prac ręcznych, takich jak szycie obuwia, palt, sukienek, fartuszków. Inne dziewczynki natomiast uczyły się rzemiosła: 2 - krawiectwa, 1 - modelarstwa, 2 - zawodu techniczki dentystycznej, 2 - zajęć komercyjnych, 2 inne, chociaż jeszcze pozostawały pod opieką Koła, już podjęły pracę. Dwie dziewczynki z sierocińca zachorowały na tyfus i zmarły, jedna była operowana, 2 przebywały w szpitalu. Latem panie zorganizowały 3-miesięczną letnią kolonię, z której korzystały wszystkie dziewczynki z sierocińca i 77 dzieci biednych. Kolonia odbyła się w majątku Ambel[ujża?], należącym do państwa Plater ${ }^{98}$. Dzieci korzystały tam z kąpieli solankowych i z ogrodu właścicieli majątku. Sierociniec Koła Pań mieścił się początkowo przy ul. Puszkarskiej 7, ale ze względu na remont domu, przeniesiono go na ul. Gularną 5. Koło zorganizowało także wigilię dla 75 dzieci i choinkę dla 166 dzieci z sierocińca i szkoły elementarnej. Przy tej okazji dzieci, dzięki pomocy proboszcza ks. K. Budkiewicza i innych dobrodziejów, otrzymały

${ }^{96}$ Ok. 150 km od Petersburga.

${ }^{97}$ Sprawozdanie z działalności Kótka Pań za 1906 r., Petersburg, [1907], s. 1-4.

${ }^{98} \mathrm{~W}$ tym sprawozdaniu nie podano bliższego określenia miejscowości, lecz dowiadujemy się tego ze sprawozdania za $1913 \mathrm{r}$. 
ciepłą odzież. W 1912 r. Koło Pań liczyło 98 członkiń rzeczywistych i 22 członków wspomagających. Do tej ostatniej grupy zaliczał się ks. Budkiewicz ${ }^{99}$.

W 1913 r. sierociniec Koła Pań dla dziewczynek przeniesiony został do rozbudowanego lokalu zakładów ks. Antoniego Maleckiego przy ul. Kiryłłowskiej. Spośród mieszkających tam dziewczynek, sześćdziesiąt rano chodziło do pracy, 41 - do szkół elementarnych, 3 - na kursy dentystyczne, 4 - do innych pracowni. Personel sierocińca składał się z kierowniczki, 1 wychowawczyni i 2 służących. Za porządek i sprzątanie odpowiadały same dziewczynki, które ponadto szyły bieliznę, pończochy, buty i pantofle. Środki na tę działalność pochodziły ze składek, z procentów od kapitału Liniewicza, z bazaru dobroczynnego. Na ten cel przeznaczono także 20\% dochodu z tzw. „Balu Polskiego”"100.

Największa część środków, zebranych przez Koło, była przeznaczana na mieszkanie i wyżywienie wychowanków, którymi się opiekowano, natomiast znacznie mniej kosztowały ubranie i zeszyty dla nich oraz pensje pracowników, ponieważ starano się, aby ich zatrudniać jak najmniej. Sporą sumę pochłonęło także urządzenie nowego lokalu przy ul. Kiryłłowskiej, do którego należało dokupować meble, urządzenia elektryczne, naczynia itd. Oprócz utrzymania tego sierocińca, Koło Pań zorganizowało, jak co roku, choinkę i wakacyjne kolonie dla dzieci w Ambelujży (stacja Wyszki). Na kolonię pojechało 146 dziewcząt z 6 opiekunami. W czasie kolonii dzieci szyły, czytały, hodowały rośliny. Każde dziecko wróciło z doniczką kwiatów ${ }^{101}$.

Aby zdobyć środki na zorganizowanie kolonii letnich w 1913 r., Koło Pań zorganizowało akcję sprzedaży kwiatka „Pierwiosnka”. Zakupiono 90 tysięcy kwiatków metalowych i 30 tysięcy batystowych, które odpowiednio przyozdobione, były sprzedawane. Zebrane pieniądze zostały przeznaczone na urządzenie kilku kolonii: kolonii Koła Pań, kolonii w Mikołajówce, kolonii gimnazjum męskiego i kolonii w Carskim Siole. W Mikołajówce na trzymiesięcznej kolonii przebywało 52 dzieci, natomiast zorganizowane w innym miejscu kolonie dla 75 chłopców trwały 2 miesiące. Osoby należące do Koło Pań spotykały się raz w tygodniu w lokalu Towarzystwa Dobroczynności przy kościele św. Katarzyny ${ }^{102}$. O tym, że Koło Pań należało do Towarzystwa Dobroczynności świadczy fakt, że jego inicjatywy znajdowały swoje odbicie także w jego sprawozdaniach.

\section{Losy Towarzystwa w czasie I wojny światowej i rewolucyjnych przemian (1914-1909).}

I wojna światowa doprowadziła do pewnych zmian w działalności Towarzystwa. Już przed wojną zaczęły powstawać inne organizacje społeczne. Spowodowało to zaangażowanie się w nich części poprzednich działaczy Towarzystwa Do-

\footnotetext{
${ }^{99}$ Sprawozdanie z działalności Kótka Pań za 1912 r., Petersburg, [1913].

${ }^{100} \mathrm{~W}$ wielu miejscowościach w okresie karnawału organizowano bale, na które zapraszano osoby z wyższych sfer, zbierając przy tej okazji ofiary na cele charytatywne.

${ }^{101}$ Sprawozdanie z działalności Kótka Pań za 1912 r., Petersburg, [1913]. s. 1-4.

${ }^{102}$ Sprawozdanie z działalności Kótka Pań za 1913 r., Petersburg [1914], s. 1-14.
} 
broczynności. Konieczność pracy dobroczynnej i społecznej wzrosła. W związku z licznym napływem uchodźców z terenów, gdzie przechodził front, powstała w Petersburgu odrębna organizacja: Polskie Towarzystwo Pomocy Ofiarom Wojny (PTPOW). Działały także organizacje społeczne i polityczne innych grup narodowościowych.

Nową inicjatywą Towarzystwa Dobroczynności, związaną również z osobą ks. A. Maleckiego i siostrami sercankami, było tzw. „gniazdo rolnicze” - „Stanisławówka”, która powstała w 1915 r. Był to folwark, znajdujący się nieopodal miejscowości Strugi Białe (dzisiaj: Strugi Krasnyje). Jej fundatorem był Stanisław Glezmer, członek Rady Państwa. Przebywali tam chłopcy niezdolni do nauki szkolnej w Petersburgu. Uczyli się oni pracy na roli. Pozostawali tam i w okresie zimowym ${ }^{103}$.

Od początku swojego istnienia Towarzystwo Dobroczynności wspierało studentów. W XX w. to wsparcie przybrało formy bardziej zorganizowane. Dzięki wsparciu Towarzystwa Dobroczynności powstała Kasa Studentów Polaków. W 1916 r. jednoczyła ona ok. 400 osób. Jej celem było wzajemne wspieranie się studentów. Miała ona majątek w wysokości 40 tys. rubli, kasę chorych, bibliote$\mathrm{kę}^{104}$. Od 1894 r. Kasa ta utrzymywała tzw. Kuchnię (lub stołówkę) Studencką. Kuchnia ta przez długie lata pozostawała placówką deficytową. Kiedy wprowadzono w niej stanowisko administratora, zaczęła przynosić dochód i rozwijać się. Jej działalność zaczęło też wspierać Polskie Towarzystwo Pomocy Ofiarom Wojny. W ciągu niepełnego 1916 r. wydała ona 2144 bezpłatne i 2064 tanie obiady, opłacane przez PTPOW. Już przed wojną Kuchnia prenumerowała ponad 50 czasopism w języku polskim, litewskim i białoruskim. Dzięki temu spełniała rolę klubu studenckiego ${ }^{105}$.

Polskie Towarzystwo Pomocy Ofiarom Wojny utworzyło bardzo wiele nowych placówek dobroczynnych: schroniska dla dorosłych, młodzieży i dzieci, bursy i pracownie. Organizacja ta korzystała z niektórych budynków Towarzystwa Dobroczynności, np. z domu pracy przy ul. Kanonierskiej. W byłym przytuł$\mathrm{ku}$ „Dobrego Pasterza” na Wyspie Wasilewskiej działał dom pracy PTPOW ${ }^{106}$.

Kiedy w 1917 r. władzę zdobyli bolszewicy, działalność bardzo zasłużonych dla społeczeństwa organizacji zakończyła się. Działacze społeczni należący do grona arystokracji i zamożni obywatele musieli wyjechać, chcąc uratować swoje życie. Majątki kościołów i organizacji religijnych zostały znacjonalizowane. Placówki dobroczynne, przejęte przez państwo i oddane pod zarząd komunistów, zostały po prostu doprowadzone do zniszczenia. Nieruchomości, jak i kapitały

${ }^{103}$ Rutkowski, Biskup Antoni Malecki, s. 47-49.

${ }^{104}$ Kasa studentów Polaków uniwersytetu piotrogradzkiego, w: Polski Kalendarz Piotrogrodzki na 1917 r., s. 178.

${ }^{105}$ Polska Kuchnia Studencka, w: Polski Kalendarz Piotrogrodzki na 1917 r., s. 178-179.

${ }^{106}$ Instytucje i stowarzyszenia polskie w Piotrogrodzie, w: Polski Kalendarz Piotrogrodzki na 1917 r., s. 186. 
w bankach, które stanowiły podstawę działania Towarzystwa Dobroczynności w czasie jego istnienia, zostały zabrane ${ }^{107}$.

O stosunku nowych władz do kościelnych organizacji dobroczynnych świadczyło nałożenie już 28 stycznia 1918 r. na prezesa Towarzystwa A. Risenkamp$\mathrm{fa}^{108}$ wysokiej kary pieniężnej za to, że przed domem należącym do Towarzystwa nie był sprzątnięty śnieg i lód ${ }^{109}$.

W związku z wojną, rewolucją i załamaniem gospodarczym, nastapiła inflacja. Działacze Towarzystwa zdali sobie sprawę, że środków na jego działalność zabraknie. Już 1 kwietnia 1918 r. stwierdzono, że nie ma środków na utrzymanie tak dobrze prosperujących dotychczas zakładów ks. Maleckiego. Na zebraniu 24 maja w obecności ks. Maleckiego stwierdzono, że Towarzystwo nie może zapewnić nawet opału dla zakładów. Aby ratować sytuację, postanowiono rozebrać drewniany dom przy ul. Kiryłłowskiej 4 i drewno wykorzystać na opał. Dopuszczono też możliwość oddania zakładów w dzierżawę ${ }^{110}$ pod warunkiem, że wychowankowie sierocińca będą mieli w dalszym ciągu możliwość nauki i pracy w zakładach ${ }^{111}$.

22 czerwca 1918 r., także w obecności ks. Maleckiego, rozpatrywano konieczność ratowania dzieci z „Władysławówki”, ponieważ zagrażała jej nacjonalizacja. 1 sierpnia księża: Budkiewicz i Malecki omawiali sprawę protestu przeciwko odebraniu „Władysławówki” przez sowieckie władze w Łudze. 9 sierpnia zarząd Towarzystwa postanowił zabrać ze znacjonalizowanej „Władysławówki” 13 chłopców wraz z wychowawczyniami i przenieść ich do Piotrogrodu ${ }^{112}$. Na zebraniu 23 września postanowiono do zarządu Towarzystwa zaprosić biskupa J. Cieplaka, uprzednio przez długie lata administrującego jako wikariusz kapitulny archidiecezją mohylowską, i inne osoby, co może świadczyć o chęci ratowania Towarzystwa przez wprowadzenie do zarządu osób z autorytetem, ale także o tym, że działaczy brakowało.

Pomysłem ks. K. Budkiewicza było zdobycie świadectw ochronnych dla instytucji kościelnych ze strony zagranicznych placówek dyplomatycznych. Takie świadectwo wydał konsulat niemiecki ${ }^{113}$. Konsulat Niemiec wydał oświadczenie, że cały majątek kościoła św. Katarzyny, w tym Towarzystwa Dobroczynności,

${ }^{107}$ Do dzisiaj zachowały się wśród niektórych dokumentów rozstrzelanego w $1923 \mathrm{r}$. proboszcza kościoła św. Katarzyny, ks. Konstantego Budkiewicza, różne bilety papierów wartościowych, które stanowiły podstawę działania Towarzystwa i pomocy, jaką udzielało. Por. BKUL, Rkp. 781, kk. 142, 145, 148, 150, 153, 156, 159, 162 - [Akty vskrytiâ sejfov]

${ }^{108}$ Gen. A. Risenkampf był ostatnim prezesem zarządu Towarzystwa Dobroczynności, piastującym to stanowisko od 1909 r. Por. Rzymskokatolickie Towarzystwo Dobroczynności przy kościele św. Katarzyny w Petersburgu, s. 7.

${ }^{109}$ BKUL, Rkp. 783 - Akta rzymskokatolickiego Towarzystwa Dobroczynności, k. 1.

${ }^{110}$ Ponieważ bolszewicy znacjonalizowali wszelką własność kościelną, nie można jej było ani sprzedać ani oddać w dzierżawę. Prawdopodobnie chodzi o tzw. „przyjęcie w dzierżawę”, tzn. podpisanie zobowiązania do użytkowania obiektów kościelnych, z nadzieja, że państwo weźmie na siebie koszty utrzymania.

${ }^{111}$ BKUL, Rkp. 783 - Akta rzymskokatolickiego Towarzystwa Dobroczynności, k. 23.

${ }^{112}$ BKUL, Rkp. 783 - Akta rzymskokatolickiego Towarzystwa Dobroczynności, k. 28.

${ }^{113}$ BKUL, Rkp. 783 - Akta rzymskokatolickiego Towarzystwa Dobroczynności, k. 30-30 odwr. 
wraz funduszami zgromadzonymi w bankach i papierach wartościowych, znajduje się pod ochroną Imperium Niemieckiego ${ }^{114}$. Podobne oświadczenie wydało przedstawicielstwo Rady Regencyjnej Królestwa Polskiego ${ }^{115}$. Z prośbą do Rady Regencyjnej o takie zaświadczenie, 23 września zwróciło się także Towarzystwo Dobroczynności ${ }^{116}$. Niestety tego typu inicjatywy nie przyniosły żadnego rezultatu.

O stopniowym zamieraniu organizacji dobroczynnych świadczy to, że kończące swoją działalność Polskie Towarzystwo Pomocy Ofiarom Wojny zwróciło Towarzystwu Dobroczynności dom przy ul. Kanonierskiej $6^{117}$, a rozpadające się Koło Pań przekazało swój majątek ks. Maleckiemu ${ }^{118}$. Nie miało to jednak większego znaczenia, ponieważ bolszewicy wszelką własność uważali za swoja, a zawładnięcie nią było jedynie kwestią czasu i taktyki. Sposoby likwidacji katolickich placówek dobroczynnych wszędzie były jednakowe. Bolszewicy z początku nie wypędzali katolickiego personelu, lecz narzucali swoją dyrekcję, często spośród polskich lub polskojęzycznych komunistów. Oni wprowadzali ateistyczny kierunek wychowawczy i równocześnie zbierali powody do oskarżenia personelu katolickiego. Ponieważ nie udawało się tego uczynić z zakładami ks. Maleckiego w Piotrogrodzie, komuniści ,polscy” przeprowadzili kilka prowokacji W 1919 r. bolszewicy ostatecznie odebrali zakłady przy ul. Kiriłłowskiej. Ks. Malecki bardzo głęboko przeżył ten akt dramatu ${ }^{119}$.

Jednakże nie mogło być złudzeń. W zmienionej sytuacji społeczno-politycznej, tego typu zakłady już nie mogły istnieć. Nowej władzy zależało na tym, aby biedne dzieci wychować na rewolucjonistów. Czasem pracujące poprzednio w katolickich placówkach osoby zakonne próbowały jak najdłużej wytrwać na poprzednich miejscach, aby ratować dusze dzieci. Musiały jednak liczyć się z represjami i śmiercią. Działalność dobroczynna, którą w czasie swojego istnienia inicjowało i rozwijało Towarzystwo Dobroczynności, nie poszła na marne. Była kontynuowana nawet $\mathrm{w}$ czasie bolszewickich represji, kiedy to katolicy śpieszyli z pomocą pozbawionemu praw duchowieństwu i uwięzionym współbraciom.

\section{Zakończenie}

W ciagu 35 lat swojego istnienia (1884-1919) Rzymskokatolickie Towarzystwo Dobroczynności przy kościele św. Katarzyny w Petersburgu stworzyło warunki autentycznego życia chrześcijańskiego dla wielu katolików, mieszkańców stolicy Rosji, rozwijało wśród nich odpowiedzialność religijna, społeczną, narodowo-patriotyczną. Roztoczyło parasol ochronny nad wieloma ukrytymi zgroma-

${ }^{114}$ BKUL, Rkp. 781, k. 70 - Ohrannoe svidetelstvo konsula Koeniga 19 IX 1918.

${ }^{115}$ BKUL, Rkp. 781, k. 72 - Ohrannoe svidetelstvo predstavitela regentskogo soveta $11 \mathrm{X}$ 1918.

${ }^{116}$ BKUL, Rkp. 783 - Akta rzymskokatolickiego Towarzystwa Dobroczynności, k. 60.

${ }^{117}$ BKUL, Rkp. 783 - Akta rzymskokatolickiego Towarzystwa Dobroczynności, k. 33-33v.

${ }_{118}$ BKUL, Rkp. 783 - Akta rzymskokatolickiego Towarzystwa Dobroczynności, k. 30-30 odwr.

${ }^{119}$ Rutkowski, Biskup Antoni Malecki, s. 63-69. 
dzeniami zakonnymi, które pracowały na jego placówkach. Działalność Towarzystwa budziła wśród wiernych postawy miłosierdzia chrześcijańskiego, zapewniała doraźną pomoc wielu ubogim katolikom, pomagała zdobyć wykształcenie tysiącom biednej młodzieży. Przygotowała zastępy odpowiedzialnych członków Kościoła i aktywnych obywateli odradzających się po I wojnie światowej krajów, zwłaszcza Polski.

\title{
РИМСКО-КАТОЛИЧЕСКОЕ БЛАГОТВОРИТЕЛЬНОЕ ОБЩЕСТВО ПРИ ХРАМЕ СВ. ЕКАТЕРИНЫ В САНКТ-ПЕТЕРБУРГЕ (1884-1919)
}

\begin{abstract}
Резюме
В течение 35-летнего существования (1884-1919) Римско-католическое Благотворительное Общество при храме св. Екатерины в Санкт-Петербурге создало условия подлинной христианской жизни для многих католиков, жителей столицы России, развивало в них религиозную, социальную и национально-патриотическую ответственность. Распростерло охранительный покров над многими тайными монашескими конгрегациями, которые работали в его учреждениях. Деятельность Благотворительного Общества побуждала верующих к христианскому милосердию, обеспечивала своевременную помощь нищим католикам, тысячам бедной молодежи помогала приобрести образование. Подготовила ряды ответственных членов Церкви и активных граждан возрождающихся после I мировой войны государств, особенно Польши.
\end{abstract}

